\title{
Prosodic structure and suprasegmental features
}

\section{Short-vowel stød in Danish}

\author{
Pavel Iosad $^{1}$
}

Received: 3 April 2015 / Accepted: 21 March 2016 / Published online: 1 September 2016

(C) The Author(s) 2016. This article is published with open access at Springerlink.com

\begin{abstract}
This paper presents a phonological analysis of a glottalization phenomenon in dialects of Danish known as 'short-vowel stød'. It is argued that both short-vowel stød and common Danish stød involve the attachment of a laryngeal feature to a prosodic node - specifically the mora. In the case of short-vowel stød that mora lacks segmental content, as it is projected top-down due to local prosodic requirements, not bottom-up by segmental material. I show that this device provides an account of the distribution of short-vowel stød as arising from the interplay of constraints on metrical structure (both lexically stored and computed by the grammar) and the requirement for morae to be featurally licensed. The analysis provides further evidence for the analysis of 'tonal accents' and related phenomena in terms of metrical structure rather than lexical tone or laryngeal features, and contributes to our understanding of the relationship between segmental and suprasegmental phonology in Germanic languages.
\end{abstract}

Keywords Danish · Stød · Suprasegmentals · Tonal accents · Metrical phonology · Moraic theory

The author and JCGL dedicate this article to Inger Ejskjær (1926-2015), professor of Danish dialectology at the University of Copenhagen from 1971 to 1996, without whose documentation and published account of short-vowel stød the present article could not have been written.

$凶$ Pavel Iosad

pavel.iosad@ed.ac.uk

1 Linguistics and English Language, The University of Edinburgh, Dugald Stewart Building,

3 Charles Street, Edinburgh EH8 9AD, UK 


\section{Introduction: suprasegmental phonology and feature theory}

Traditionally, the theory of phonological features has focused on (sub)segmental representations, that is, on features that distinguish the segments (or phonemes) of a particular language. The nature (and existence) of featural representations in the suprasegmental domain remains more problematic: Yip (2002: chapter 3) provides a useful summary of some approaches to tone, but overall there seems to be little agreement (see Clements et al. 2010; Hyman 2010; Odden 2010 for three very different accounts). There are still relatively few unified treatments of features relevant to both subsegmental and suprasegmental contexts (although see Lodge 1993, 2007; Bradshaw 1999; Kehrein and Golston 2004; Pearce 2013; Golston and Kehrein 2015), and the relevance of suprasegmental facts to debates familiar from theories of segmental phonology also often remains unclear.

In this paper I consider the phenomenon of 'short-vowel stød' in Zealand Danish, which involves glottal activity associated with phonologically short vowels, unlike the more familiar and much-researched common Danish st $\varnothing$ de.g., Hansen 1943; FischerJørgensen 1989; Grønnum and Basbøll 2001; Basbøll 2005). I suggest that stød is represented as a laryngeal feature, which I write as [constricted glottis], or [c.g.] for convenience (e.g., Halle and Stevens 1971; Avery and Idsardi 2001), attached directly to the moraic node rather than being subsegmental, i.e., dominated by a root node. The difference between short-vowel stød and common Danish stød lies in the fact that the former is associated with a mora that is not projected 'bottom-up' by a segment. Instead, this mora is inserted due to 'top-down' requirements on the branching of prosodic constituents. I suggest that such morae have to be licensed by a phonological feature; for lack of segmental material, Zealand dialects use the same feature [c.g.] as in the case of common Danish stød to achieve this licensing.

The proposed analysis bears both on the nature of suprasegmental featural representations and on the analysis of 'tonal accent' systems. The [c.g.] feature is not qualitatively different from distinctive features in the subsegmental domain (such as, indeed, [c.g.] as commonly used to encode phonetic properties such as 'ejective' and 'glottalized'). In other words, the association of features with root nodes is not a hard constraint on the architecture of phonological representations. Given this blurring of the lines between 'subsegmental' and 'suprasegmental' features, the analysis brings out the close relationship between stød and 'tonal accents'. This similarity is even more pronounced if we accept recent analyses of North and West Germanic 'tonal accent' systems in terms of lexically specific metrical structure coupled with general mechanisms for the assignment of tone (Morén-Duolljá 2013; Kehrein 2016; Hermans 2009, 2012; Köhnlein 2011, 2016; van Oostendorp 2016) rather than the traditional view of lexical tones.

In Sect. 2 I provide a very brief overview of the nature of common Danish stød and introduce some of the representational machinery used in this paper. Section 3 presents relevant data from Zealand Danish, with reference to both short-vowel stød and the covert 'tonal accent' system of this variety. The analysis is provided in Sect. 4, where I discuss its representational aspects and account for the distribution of short-vowel stød using Optimality Theory. In Sect. 5 I discuss the relevance of the results in a broader context, with particular reference to the controversy over the proper representation of 
'tonal accent', and show some broader applicability of the representational devices proposed in the paper. Section 6 provides a brief conclusion.

\section{Common Danish stød}

Danish is well known for the phenomenon of stød, manifested mostly as glottalization on vowels and sonorants (Fischer-Jørgensen 1989). The literature on the phonetics and phonology of stød is enormous; a brief overview can be found in Grønnum and Basbøll (2001), while Basbøll (2005) provides a wide-ranging discussion of numerous aspects of the behaviour of stød in Standard Danish. ${ }^{1}$ This type of st $\varnothing \mathrm{d}$ generally corresponds historically to the 'accent 1' of Norwegian and Swedish dialects, and appears in most varieties of Danish. I will call this type the 'common Danish stød', using a calque from the convenient Danish term fallesdansk. Although the conditioning of the common Danish stød is not the prime focus of the present paper (and it would be impossible to do full justice to the facts here), in this section I provide an overview of those aspects of the phenomenon that are relevant for the present purposes. I mostly follow Basbøll (2003, 2005: et passim) in the analysis.

Despite all the intricacies of common Danish stød, it submits to several phonological generalizations. Perhaps the most important among these is the existence of the socalled 'stød basis', i.e., the minimal domain in which stød may appear. Basbøll (2005: 277) describes it as follows:

"The notion 'stød-basis'... covers two kinds of conditions for a syllable to have stød, namely, (i) a segmental condition: it should have either a long vowel or a short vowel followed by a sonorant consonant; and (ii) a prosodic condition: it should either have primary or secondary stress."

Basbøll (2005) convincingly argues that the proper phonological interpretation of the 'stød basis' notion is a bimoraic syllable (assuming only sonorants contribute to weight in Danish; see Zec 1988; Morén 2001 for discussion of relevant restrictions), and I adopt this analysis here.

Basbøll (2005) argues that stød is the default specification of a second mora in a Danish syllable, i.e., that all bimoraic syllables have stød unless a particular factor intervenes. These factors can be lexical (e.g., lexical extrametricality, which prevents a potentially sonorous coda from projecting a mora) or morphological (certain morphological structures are more or less conducive to stød), but in their absence the phonological computation enforces stød on such morae. ${ }^{2}$

While Basbøll (2005) is relatively agnostic on the exact phonological representation of stød in Danish, other authors have proposed to view stød as an essentially tonal phenomenon, in effect the phonetic realization of a rapidly falling tone (Itô and Mester 1997; Riad 2000b, 2009; Morén 2003). ${ }^{3}$ However, Grønnum et al. (2013) provide

\footnotetext{
1 See Basbøll (2005: 12-16) for discussion of the sociolinguistic content of the term 'Standard Danish'.

2 I address some empirical objections to this view of common Danish stød below in Sect. 5.4.

3 The relationship between falling tone and creakiness (glottalization) can also be established in other North Germanic dialects (Riad 2000a; Hognestad 2007) and Livonian (Kiparsky 2016).
} 
arguments against this approach, and defend the 'reification of stød as a non-tonal phonological object' (Riad 2009: 12). The analysis presented here is compatible with the position of Grønnum et al. (2013): irrespective of whether Riad (2000a, b, 2009) is correct with respect to the tonal origin of common Danish stød, synchronically it is seen as a single object attaching to a particular node in the metrical structure, not a composite tonal entity. More specifically, I propose that common Danish stød in a word like ['hal'] 'hall' (hal) is represented as follows:

Common Danish stød: ['hal'] 'hall'

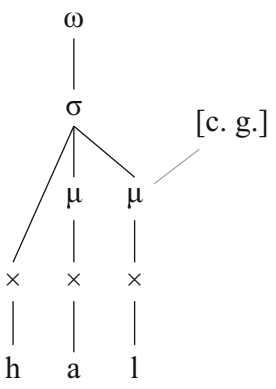

Here, the second mora of the stressed syllable is associated with both segmental content (the consonant [1]) and with the suprasegmental feature [c.g.], which is phonetically realized as creakiness on the sonorant (with some attendant effects such as higher tone on the vowel; see Fischer-Jørgensen 1989).

With this minimum of information regarding the common Danish stød, we now turn to short-vowel stød.

\section{Short-vowel stød: data}

In this paper I concentrate on a type of stød found in the dialects of the island of Zealand (Sjælland), which Ejskjær (1967) calls 'short-vowel stød' (kortvokalst $\varnothing d$ ). Short-vowel st $\varnothing \mathrm{d}$ is found in syllables containing a short vowel that are either open, or closed by obstruents rather than sonorants. In this respect, it contrasts with common Danish stød: the latter is also found in these varieties, but, as noted above, it is not associated with open light syllables, nor with syllables with a short vowel and a nonsonorant coda. As also noted above, Basbøll (2005: et passim) analyses syllables that are able to bear common Danish stød as bimoraic, and those that are unable to do so as monomoraic. In this paper, I shall argue that syllables bearing short-vowel st $\varnothing \mathrm{d}$ are also bimoraic, despite the apparent lack of sufficiently sonorous rhymal material; I suggest that the second mora in such syllables is instead segmentally empty. (See below Sect. 5.4 for discussion of non-stød bearing, nonmoraic coda obstruents).

In this section I review the evidence for a phonological contrast between common Danish st $\varnothing \mathrm{d}$ and short-vowel st $\varnothing \mathrm{d}$ and then discuss the distribution of short-vowel st $\varnothing \mathrm{d}$ in a number of straightforward cases. In Sect. 3.3 I turn to a more complex class of words with short-vowel stød, namely those that have historically undergone apocope of a final schwa. I show that phonologically these words retain a second syllable, and that 
such apocopated words demonstrate expected behaviour with respect to short-vowel stød.

The data in this section come from Ejskjær (1965, 1967, 1970) and Geist (1976); I refer to these works for in-depth description of the facts. ${ }^{4}$ These sources use the Dania transcription system; here, I retranscribe forms using IPA, based on Kristensen (1924) and Basbøll (2005: Appendix 1).

\subsection{The phonological status of short-vowel stød}

Short vowel stød is characteristic of some traditional dialects of the island of Zealand (Sjælland), mostly those spoken in a wide east-west belt in the central part of the island and also on the northernmost coast (see, e.g., the map in Ejskjær 2006). The descriptions by Ejskjær (1967) and Geist (1976) include data from the dialect of the parish of Strøby in the south-east of Zealand on the Stevns peninsula (also the subject of the longer Ejskjær 1970), as well as from Højby (north-west Zealand), Alslev (south of Strøby), Skørpinge (south-west Zealand), Glums $\varnothing$ in the central region of the island, and Glæn $\varnothing$, an island off the south-west coast of Zealand.

In Zealand Danish, common Danish stød coexists with stød that is associated with a short vowel followed by a voiceless fricative or a stop (or a cluster of two such consonants). Note that there is no laryngeal stop contrast in non-foot-initial position in Danish: the non-syllable-initial unaspirated stops [b d g] alternate almost exceptionlessly with syllable-initial aspirated stops: Standard Danish ['lag̊] lak 'lacquer', [la' $\mathrm{k}^{\mathrm{h}} \mathrm{e}$ : 'ə] lakere 'to lacquer'. Given this lack of contrast, it is not immediately obvious what the laryngeal specification for these medial stops is, and they certainly cannot be assumed to bear the feature [+voice] that would be required for them to have high sonority. ${ }^{5}$ Thus, when Ejskjær (1967) says that short-vowel stød is found after a short vowel before [ $\mathrm{pt} \mathrm{k \textrm {fs }}$, and clusters containing these consonants, this essentially means short-vowel stød is in complementary distribution with common Danish stød, in that it appears in syllables whose rhymes cannot support a second mora. For instance, this happens when the stressed syllable is open and has a short vowel.

\section{Short-vowel stød in Zealand Danish}

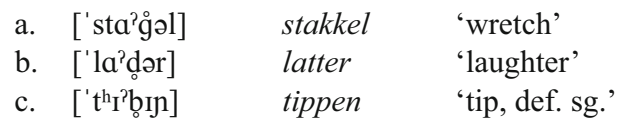

\footnotetext{
${ }^{4}$ According to Asgerd Gudiksen and Jan Heegaard (p. c.), short-vowel stød today is moribund. Although some elderly rural speakers still use it (perhaps sporadically), it can be absent even in otherwise traditional speech. (Thanks to an anonymous reviewer for checking these facts).

5 In Standard Danish, word-medial stops are unaspirated and categorically devoiced (Hutters 1985; Basbøll 2005). For Zealand Danish Ejskjær (1970) claims that both voiced and voiceless realizations are possible, with a preference for voiced realizations word-medially. This could be consistent with an account along the lines of Iverson and Salmons (1995), Hsu (1998), Jessen and Ringen (2002), Jansen (2004) and Honeybone (2005), where the variation could result from lack of phonological laryngeal specification, but in the absence of detailed instrumental data on the Zealand dialect I will refrain from further speculation.
} 
Unlike common Danish stød, short-vowel stød is restricted to polysyllabic words. In monosyllables containing short vowels followed by (clusters of) [p t k f s], the vowel cannot bear stød:
a. $\left[\mathrm{k}^{\mathrm{h}} \mathrm{na}\left({ }^{* ?}\right) \stackrel{\mathrm{g}}{\mathrm{g}}\right]$
knakk
b. ['bre $(* ?) \mathrm{d}]$
bred
'to break, past'
c. $[$ ' $\mathrm{g} l \mathrm{la}(* ?) \mathrm{s}]$
glas
'wide'
'glass'

Short-vowel stød also phonologically contrasts with common Danish st $\varnothing$ d that appears on long vowels, as discussed by Ejskjær (1967: 12-14). The number of (sub)minimal pairs is not great, due partly to the fact that Old Danish long vowels tend to be reflected as diphthongs in the Zealand dialect, as in many other island varieties (see, e.g., Hansen 1962). Nevertheless, (sub)minimal pairs contrasting stød on short and long vowels are found in the dialect:
a. $\left[\mathrm{p}^{\mathrm{h}} \Lambda^{\mathrm{T}} \mathrm{d} \mathrm{g}\right] \mathrm{potten}$
b. ['brs:?din] brodden
'pot (obsolete unit of measurement), def. sg.'
a. ['brø'g̊ge]
brygger
b. ['brø:?ำ]
brøker
'to brew, pres.'
'fraction, pl.'
a. ['na?dən]
natten
'night, def. sg.'
b. [g̊ra'na:?dən]
granaten
'grenade, def. sg.'

Thus, stød on short and long vowels corresponds to different phonological representations in the language. This difference is further buttressed by the fact that the distribution of short-vowel stød does not perfectly align with the number of syllables in the word at the Old North Germanic stage and hence with the 'accent 1'/'accent 2' contrasts in Norwegian and Swedish (Ejskjær 1967: chap. 2). In particular, we only find relatively few examples of systematic prosodic alternations such as those in Swedish ${ }^{2}$ kyssa 'to kiss' (old disyllable, accent 2 ) versus ${ }^{1}$ kysser 'kiss, present' (old monosyllable, accent 1). I return to this issue in more detail in Sect. 5.2.

Having established the existence of a phonological distinction between short-vowel stød and common Danish stød, we turn to a description of contexts where the shortvowel stød is found in Zealand Danish.

\subsection{Unpredictable and predictable stød}

In underived forms, the distribution of short-vowel stød is unpredictable: some words of the right phonological shape bear stød, and others do not. Compare the following examples: 
(7) Short-vowel stød
a. ['sta’gol $]$
stakkel
'wretch'
b. $\left[{ }^{2} \varepsilon^{2} \mathrm{de}\right]$
efter
'after'
c. ['fa'ste]
faster
'aunt'

(8) No short-vowel stød
a. ['knlabe]
klapper
'clapper'
b. ['theskəl]
toerskel
'threshold'
c. [k ${ }^{\text {ha }}$ 'rafəl $]$
karaffel
'jug'

In this respect, short-vowel stød is parallel to common Danish stød, which is lexically distributed in underived forms: ['ven] 'friend' (ven) but [' $\mathrm{p}^{\mathrm{h}} \varepsilon \mathrm{n}^{\text {? }] ~ ' n i c e ' ~(p e n) . ~}$

The same is true in certain morphologically complex forms:

(9) Short-vowel stød
a. $\left[\varepsilon^{2} s \in\right]$
esser
b. ['n $\left.\varepsilon^{2} d e\right]$
noetter
'ace (playing card), pl.'
c. ['brø’g̊ge]
brygger
'night, pl.'
'to brew, pres.'

(10) No short-vowel stød
a. ['lebo
lapper
'sheet of paper, pl.'
b. ['dofte]
dufter
'smell, pl.'
c. ['thabe $]$
taber
'to lose, pres.'

The unpredictability of the distribution in these contexts means that whatever motivates the appearance of stød here, it definitely does not follow exclusively from the phonological shape of the word; in other words, the distribution here is lexically and/or morphologically conditioned at least to a certain extent. In this respect, again, there are parallels with common Danish stød, whose distribution in derived forms is at least partly lexically and morphologically circumscribed; for instance, in the following partial noun paradigms the presence of stød alternations between the singular and plural is not solely driven by the phonological context ${ }^{6}$ :
a. ['han]
han 'male'
b. ['han'e]
hanner 'males'
a. ['ven]
ven
'friend'
b. ['vene]
venner
'friends'

\footnotetext{
${ }^{6}$ Specifically, under the analysis of Basbøll (2005), stød in hanner represents the productive model, whilst venner lacks stød because the morphosyntactic properties of the plural suffix in this form force the creation of a domain structure that is different from that of hanner and does not require stød.
} 
However, there are at least two contexts where short-vowel st $\varnothing \mathrm{d}$ is required irrespective of lexical conditioning, i.e., wherever the two important conditions of bisyllabicity and coda make-up are met.

One of these is the definite singular form of monosyllabic words. Recall that monosyllables generally do not bear short-vowel st $\varnothing \mathrm{d}$; however, the addition of the postposed definite article always leads to short-vowel stød:
a. ['løst]
lyst
'desire'
b. ['lø'stən] lysten
'desire, def. sg.'

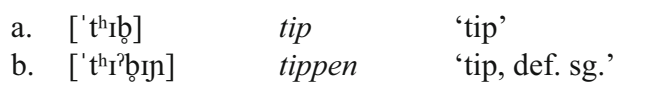

Here the parallel with common Danish stød is pervasive: even words like ['ven] 'friend' that have stød neither in the singular nor in the plural in indefinite forms regularly acquire stød in the definite singular: ['ven? $\left.{ }_{1}\right]$ 'the friend' (vennen); this parallel will be accounted for in the analysis below.

A second context where short-vowel stød is invariably found in Zealand Danish is in the second part of a compound, again provided that the underlying form is both disyllabic and does not provide a coda of sufficient sonority for the first syllable. Thus, even if the word in isolation does not bear short-vowel stød, secondary stress in the compound requires the appearance of the stød:
a. ['brøg̊日) brygger 'brewer'
b. ['øl,brø’g̊日e] ølbrygger 'beer-brewer'
a. ['hog̊日 ] hugger 'cutter'
b. ['klamb, ho?g̊ge $]$ klamphugger 'sloppy worker'

Finally, we find obligatory short-vowel stød on verbal roots when preceded by the unstressed prefixes be- and for- (and followed by another syllable):
a. [f $\Lambda$ ' $\mathrm{p}^{\mathrm{h}}$ i'skəð] forpisket 'to whip, past participle'
b. [f $\mathrm{f}^{\prime}$ lø'stəlsə] forlystelse 'entertainment'
c. [be'ny'də] benytte 'to use, inf.'

Note that the identity of the first unstressed syllable as a prefix is crucial: words with a similar prosody that do not contain a prefix may have short-vowel stød, but it is not obligatory:

(18) Short-vowel stød

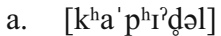
kapitel 'chapter'
b. [re'g̊̀iste]
register 'list' 
(19) No short-vowel stød
a. [mi'rag̊al]
mirakel 'miracle'
b. [spı' thagol]
spektakel 'noise'

Both the compound stød and the prefixal stød appear to be manifestation of the same phenomenon as 'new stød' (nystød; Hansen 1943), whereby second elements in compound prosodic words and following unstressed prefixes tend to receive stød even when it is absent in morphologically simpler forms, whether of the common Danish or the short-vowel variety:

(20) Common Danish 'new stød' with a stressed prefix:
a. ['velə]
valde 'to rush'
b. ['pw $\left.\Lambda, v^{2} l^{\prime} ə\right]$
overveelde 'to overwhelm'

(21) Common Danish 'new stød' with an unstressed prefix:
a. ['th $\mathrm{t}^{\mathrm{g}} \mathrm{l}$ ')]
b. $\left[\mathrm{f}_{\Lambda}{ }^{\prime} \mathrm{t}^{\mathrm{h}} \varepsilon \mathrm{l}^{\mathrm{P}} \partial\right]$
toelle
'to count'
fortcelle
'to recount, tell'

Before we continue to the analysis of short-vowel stød, I discuss the behaviour of disyllables with (historical) final [ə].

\subsection{Apocope and 'tonal accent' in Zealand Danish}

All examples of words with short-vowel stød in the previous section involve words where the syllable following the stressed one contains a sequence of schwa and a sonorant ([n], [1] or [ð]) or the segment [e], phonologically [r] or at least derived from /ər/ in Danish, see the discussion in Basbøll (2005). Given the phonotactics and morphology of Danish, we expect many words to have the shape $\mathrm{CVC}(\mathrm{C})$, , but these are not represented in the previous section. Here, I discuss the historical development and synchronic structure of such words, and argue, following in many respects Ejskjær (1970), that they should be treated together with the disyllables discussed in the previous section.

Many Danish dialects are characterized by historical apocope of word-final schwa. In the dialects of Jutland the apocope is categorically present, but many island dialects show variability in apocope; examples of such varieties are the dialects of Funen and Zealand. The description of the Eastern Funen dialect by Andersen (1958) only refers to 'variability' in the realization of the final schwa in forms such as ['følə] 'to follow' (følge), ['grisə] 'pigs' (grise), and ['hıbə] 'to hop' (hoppe). For Zealand, however, more reliable data are available, in particular in Larsen (1976). In Ejskjær (1967, 1970), the final schwa is generally not written, whereas the word-final consonant is normally written as long: ['føl:], ['ğris:], ['hıbo:].

Nevertheless, Larsen (1976) shows that pairs such as ['gris] 'pig' and ['gris:] 'pigs' are normally distinct in the Zealand dialect. The distinction can be expressed in a number of ways. The final schwa in historically disyllabic words is normally, but not 
categorically, absent, and thus may contribute to the distinction. It is, however, not the only, or even the main realization of the contrast.

In particular, forms written by Ejskjær as ['hıb:] and ['goris:], where the second consonant is a voiceless obstruent, contrast with ['h $\Lambda$ b] and ['g̊ris] in terms of their pitch contour: Larsen (1976) describes the contour in the apocopated words as having a 'smoother and later rise' (,jævnere og senere rejsning“") than the historically monosyllabic words. In cases like ['føl:], i.e., words with a final sonorant, the contrast is expressed as one of length of the sonorant in addition to the pitch accent.

Further, as Ejskjær (1970) notes, the structural contrast between monosyllabic and apocopated words is preserved in sonorant-final items when such forms become second members of a compound and bear secondary stress. ${ }^{7}$ As noted above, in stems that have the right phonological properties that position requires the appearance of stød, whether short-vowel or common Danish. Crucially, the presence of the apocopated schwa makes a difference to the phonetic realization of what appear to be stød-bearing sonorant codas, as demonstrated by pairs such as the following:
a. ['elə, vil']
ellevild 'wild'
b. ['Elo, vil:']
ellevilde
'wild, pl.'
a. $\left[{ }^{\wedge} \Lambda m_{1} v \varepsilon n^{2}\right]$
omvend
'turn around, imp.'
b. [' $\left.\Lambda m_{1} v \varepsilon n: '\right]$
omvende
'turn around, inf.'

In forms with monosyllabic second components (as in ellevild and omvend!), the stød-bearing sonorant is voiceless, with no voice bar and no formant structure visible on the spectrogram. In their apocopated counterparts (ellevilde and omvende), the presence of the stød does not inhibit full voicing of the sonorant (Ejskjær 1970, 41).

The maintenance of this contrast leads Ejskjær (1967, 1970), who works in the strongly structuralist-influenced Danish grammatical tradition, to interpret forms such as ['gris:] 'pigs' as containing a phonemic final schwa (/grisə/). I suggest, instead, that while the basic insight — the phonologically disyllabic status of such words — is sound, a treatment in terms of a final segment is not appropriate. Instead, I suggest that the surface representation of these forms contains just enough suprasegmental structure to provide a well-formed syllable (i.e., the syllable node itself and the nuclear mora), but the nuclear mora does not dominate any segments, as shown in (24). ${ }^{8}$

\footnotetext{
7 I use the word 'compound' loosely here, to include both compounds with two roots and particle verbs; their behaviour for our purposes is identical.

8 For concreteness, I treat the nonmoraic consonant here as an onset (of an unstressed syllable). Basbøll (2005) treats such consonants as crisply captured codas, mostly to explain their behaviour in consonant gradation; this may, however, not be necessary if the facts of Danish consonant gradation can be described in terms of foot-initial versus foot-non-initial position (cf. Harris 2012 for English). As far as I can see, neither option makes a difference for the account of the facts at hand.
} 


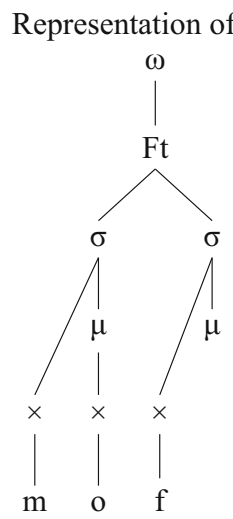

This representation is different from that proposed for Standard Danish by Basbøll (2005: §11.5), who suggests that 'schwa-assimilated' words like ['mas] 'mass' (masse, with variant form ['masə]) are monosyllabic, with the obstruent treated as a nonmoraic coda. This analysis is partly based on the fact that such forms in Standard Danish are not distinct from underlyingly monosyllabic ones like ['mas] 'Mads (personal name)'. This cannot be the case in Zealand Danish, since the contrast is still expressed by pitch movement and other means. ${ }^{9}$

In fact, the contrast between ['hıb] 'hop' and ['hıb_] 'to hop' could be described as one of tonal accent (cf. Ringgaard 1960a; Ejskjær 1990), although the distribution of these accents is quite different from the familiar accent 1 versus accent 2 contrast of Norwegian and Swedish. Specifically, in Zealand Danish the 'tonal accent' distinguishes between what appear to be monosyllables, whereas in most varieties of Norwegian and Swedish monosyllables neutralize the accent contrast. I suggest that the pitch contrast between ['hıb] 'hop' and ['hıb_] 'to hop' is best expressed as a contrast in the number of syllables, with the latter represented as in (24). Thus, the 'tonal accent' contrast involves not distinctive tones but rather distinctive metrical structure, coupled with a general rather than lexically specific mechanism for the assignment of tone. This proposal fits quite well with the approach of Larsen (1976), who suggests that mono- and polysyllables in Zealand Danish differ not in the tonal contour itself but in the fact that in monosyllables the contour is spread over a larger domain.

More specifically, the second mora in a form like ['h $\Lambda$ b_] 'to hop' provides a later landing site for a high tone, leading to the smoother rise throughout the initial syllable. Absent a detailed description of the intonation system of the language, I will, for simplicity, assume a L*H melody for the stressed syllable (cf. Donegal Irish, Dalton and Ní Chasaide (2005), and Köhnlein (2013) for more discussion of declarative rising contours and their role in the genesis of 'tonal accents'). It may be worth noting that the intonational system of Standard (Copenhagen) Danish is, in fact, described as having a low pitch accent on the stressed syllable followed by a high tone initiating a fall on the following syllable(s) (e.g., Grønnum 1998).

\footnotetext{
${ }^{9}$ For a discussion of pitch in schwa-assimilated words (including obstruent-final ones) in Standard Danish, see Thorsen (1982).
} 
In a monosyllabic form such as ['h $\Lambda$ b] 'hop', both the $\mathrm{L}^{*}$ and the $\mathrm{H}$ tones are associated to the initial syllable to give a relatively steep rise, whereas in a disyllabic ['hıb_] 'to hop' the $\mathrm{H}$ tone gets associated to the second syllable, producing the 'smoother and later rise': this is expected to be the case even if only a portion of the rhyme is voiced and so can support pitch (as in ['hıb_]). ${ }^{10}$ The difference is illustrated in $(25)$.

a. Tonal representation of [' $h \wedge b]$ 'hop'

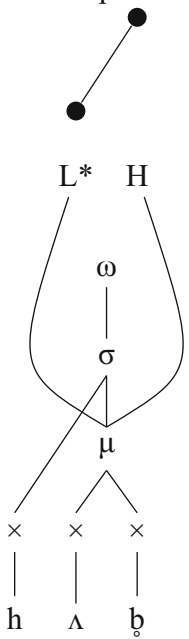

b. Tonal representation of [' $\left.\mathrm{h} \Lambda \mathrm{b} \_\right]$'to hop'

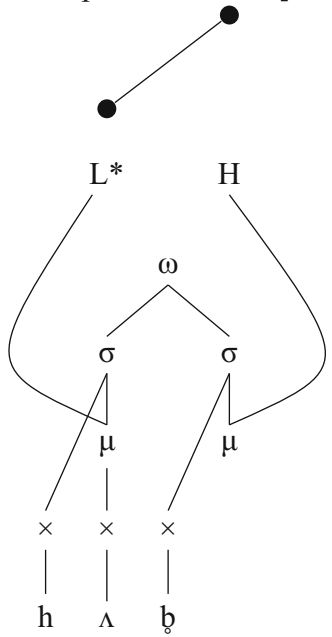

10 Other interpretations are available, of course: for instance, one could see the pitch accent as a $\mathrm{H}^{*}$ tone that is realized later in phonologically disyllabic words due to peak delay. This does not change the fundamental phonological generalization. 
Since it is the timing of the pitch contours, rather than the presence of a schwa-like portion of the signal, that appears to be the main correlate of the contrast in Zealand Danish, I suggest that postulating a word-final phonological schwa in these cases is no longer warranted. A [ə]-type acoustic phenomenon is a not an a priori unreasonable phonetic implementation of an empty nucleus, especially given that the second syllable is also required to host a tone. The alternative of assuming a word-final schwa in the output of phonology would require a gradient phonetic implementation rule with an unclear status.

I do not consider sonorant-final forms such as ['føl:] 'to follow' in detail here; it might well be that they have the representations proposed by Basbøll (2005), which do not involve empty nuclei. However, since any stød in such forms is of the common Danish rather than the short-vowel variety, they are a relatively peripheral concern for the purposes of the present paper.

Having established the phonological representation of forms such as ['h $\mathrm{L}_{\circ}$ ] 'to hop', we will now consider their behaviour with respect to short-vowel stød.

\subsection{Short-vowel stød in apocopated words}

The distribution of short-vowel stød in apocopated words is essentially identical to its distribution in the forms described in Sect. 3.2. Thus, for instance, in underived forms of the right phonological shape the distribution of stød is lexically determined (although apparently the number of such words with stød is very small).

(26) Short-vowel stød
a. ['si'st]
sidste
'last'
b. [' $\mathrm{e}^{\mathrm{g}} \mathrm{g}$
ikke
'not'
c. $\left[{ }^{2} \Lambda^{2} \mathrm{~s}\right]$
også
'too, also'

(27) No short-vowel stød
a. ['p $\left.\mathrm{p}^{\mathrm{h}} \mathrm{ub}\right]$
puppe
'larva'
b. ['dys]
dysse
'dolmen'
c. ['bøs]
bøsse
'rifle'

Note that apparently no CVC_ nouns have short-vowel stød; given that CVCəS (where $\mathrm{S}$ is a sonorant) nouns do appear to take stød quite freely, this could be a historical gap rather than a real one. Crucially, $\mathrm{CVC}_{-}$nouns also fail to acquire shortvowel st $\varnothing \mathrm{d}$ in the definite singular form, even though it is obligatory for CVC nouns:

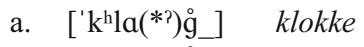
'bell'
b. ['k $\left.\mathrm{k}^{\mathrm{h}} \mathrm{la}\left(*^{2}\right) \stackrel{\mathrm{g}}{\mathrm{a}} \mathrm{n}\right]$ klokken 'bell, def. sg.'

Short-vowel stød is also possible when the relevant stem is preceded by an unstressed syllable or another stem in a compound. For the purposes of this generalization, apocopated words also behave like other monosyllables. In cases of possible 
stød (the stem being preceded by an unstressed syllable other than the prefix be- or for-), short-vowel st $\varnothing \mathrm{d}$ is possible but not obligatory:

(29) Short-vowel stød
a. $\left[\mathrm{p}^{\mathrm{h}} \mathrm{ren}\right.$ 's $\varepsilon^{\mathrm{T}} \mathrm{s}$
b. $\left[\Lambda^{\prime} \mathrm{m} \Lambda^{2} \mathrm{~s} \_\right]$
prinsesse
'princess'
om også 'even if'

(30) No short-vowel stød
a. [a'dres_]
adresse
'address'
b. [ra'dask $]$
radaske
'good-for-nothing woman'

When the short-vowel stød is obligatory (i.e., following unstressed be- and for-and as the second element in a compound), $\mathrm{CVC}_{-}$forms behave like any other disyllabic form and take the stød even if it is absent in isolation:
a. ['had_]
hatte
'hat, pl.'
b. ['halm, ha'd_] halmhatte 'straw hat, pl.'
a. ['ask_]
aske
'ash'
b. ['p $\left.\mathrm{p}^{\mathrm{h}} \Lambda \mathrm{d}, \mathrm{a}^{2} \mathrm{sk}\right]$ potaske 'potash'

[be're'd_] berette 'tell, inf.'

To sum up the distribution of short-vowel stød, it is found in disyllabic forms, where the first syllable has a short vowel and the stem does not provide melodic material of sufficient sonority to project a second mora. Adopting the traditional terminology used for common Danish stød, I shall refer to forms whose phonological make-up is compatible with exhibiting short-vowel stød, as having a basis for short-vowel stød.

In certain contexts, short-vowel stød is obligatory, subject to these phonological restrictions; in others, its presence is possible but not obligatory. In the next section I provide an analysis of short-vowel stød.

\section{Analysis}

Given the analysis of common Danish stød as involving a [c.g.] feature on a second mora projected by a segment in Sect. 2, I propose to view short-vowel st $\varnothing \mathrm{d}$ as being the realization of an essentially similar structure, albeit with the second mora not dominating a segmental node. Thus, the contrast between ['brø:? goe] 'fractions' (brøker), with common Danish stød, and ['brø’g̊g] 'to brew, present' (brygger), with short-vowel stød, is represented as in (34). 
a. Common Danish stød: ['brø:?g̊g] 'fractions'

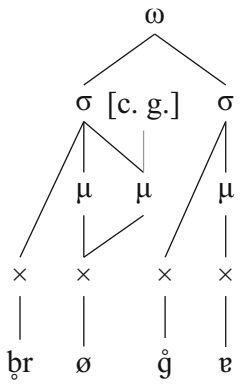

b. Short vowel stød: ['brø’g̊日] 'to brew, pres.'

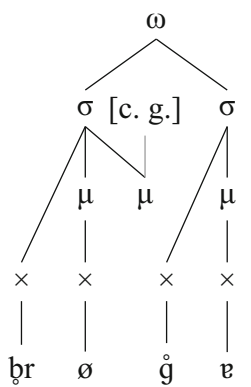

With these representations in mind, we turn to the analysis of the distribution of short-vowel stød. It will be useful to distinguish between three subcases:

(i) The definite singular of nouns: obligatory short-vowel stød for CVC nouns, obligatory lack of short-vowel stød for $\mathrm{CVC}_{-}$nouns.

(ii) Forms with unstressed prefixes.

(iii) Underived forms with short-vowel stød.

I will argue that short-vowel st $\varnothing$ d is licensed only in a particular prosodic context, namely that in a recursive foot (e.g., Selkirk 1980; Prince 1980; Dresher and Lahiri 1991; Rice 1992; Jensen 2000; Caballero 2011; Bennett 2012; Martínez-Paricio 2013; Kager and Martínez-Paricio 2014). The definite article clitics force the construction of a recursive foot when adjoining to $\mathrm{CVC}$ forms but not when adjoining to $\mathrm{CVC}_{-}$ones, which accounts for the difference between these two types of nouns. This requirement for short-vowel stød to be licensed by higher-level metrical structure also provides a reason for the absence of $\mathrm{CV}^{2} \mathrm{C}$ forms, as these lack the melodic material to construct a recursive foot.

\subsection{Short-vowel stød and enclisis}

In this section I argue that short-vowel stød must be licensed by a metrical structure that is constructed when an enclitic cannot use pre-specified structure and has to project a syllable in order to be correctly parsed. This situation arises particularly with the definite singular forms of CVC nouns, so we start the analysis there. 


\subsubsection{Obligatory short-vowel stød and non-minimality}

Short-vowel stød is obligatory in the definite singular forms of monosyllabic nouns (which I shall refer to as CVC for convenience) of the right phonological shape, even if the underived form lacks short-vowel stød. This applies to nouns of both genders, so the stød is not necessarily tied to a particular definiteness morpheme.

(14, repeated)

Common gender
a. ['t'th $\mathrm{ib}]$
b. ['th $\left.{ }^{\mathrm{h}}{ }^{2} \mathrm{~b} I \mathrm{I}\right]$
tip
'tip'
tippen
'tip, def. sg.'

(35) Neuter gender
a. ['vag̊s]
voks
'wax'
b. ['va'gs
vokset
'wax, def. sg.'

Although the definite forms of $\mathrm{CVC}_{-}$nouns appear to have the same phonological shape as those of CVC nouns, there is no obligatory short-vowel stød:
a. ['mof]
muffe
'muff'
b. ['mofən]
muffen
'muff, def. sg.'

(28, repeated)
a. ['k $\mathrm{k}$ lag̊_]
klokke
'bell'
b. ['k klag̊on $]$ klokken
'bell, def. sg.'

I suggest that the appearance of short-vowel stød is driven by the special prosody of singular definite forms. As in other North Germanic languages, definiteness in Zealand Danish is expressed by the so-called postposed definite article, which takes the form /ən/ in the common gender and /əð/ in the neuter gender respectively (phonetically also [n] and [ð]]). In many North Germanic varieties, these definiteness markers exhibit special prosodic behaviour. In particular, while they interact in non-trivial ways with common Danish stød (a point to which we shall momentarily return), it is important to note that in Norwegian and Swedish their presence does not change the tonal accent of the word. The fact that they are outside the domain of tonal accent assignment leads authors such as Wetterlin (2010: $\$ 4.2 .1 .2$, for Norwegian) and Morén-Duolljá (2013, for Swedish) to treat them as enclitics rather than inflectional morphemes (see also Lahiri et al. 2005b; although contrast Riad 2014: $\$ 10.5 .2$, where these are treated as prosodically neutral suffixes). I suggest that this interpretation can usefully be transplanted to Zealand Danish.

For the purposes of this paper, I assume that the property of being a (prosodic) clitic entails adjoining to a foot rather than being incorporated into it. I suggest that the definite morphemes /ən/ or /əð/ are encliticized just in the case where they have to project a nucleus. Assuming that clitics are adjoined to a foot to form a recursive foot, we arrive at the following metrical structure for the definite singular [ $\left.\mathrm{t}^{\mathrm{h}} \mathrm{I}{ }^{\mathrm{b}} \mathrm{b}_{\mathrm{o}} \mathrm{I}\right]$ 'the tip' (the importance of the circled and squared nodes is explained below): 


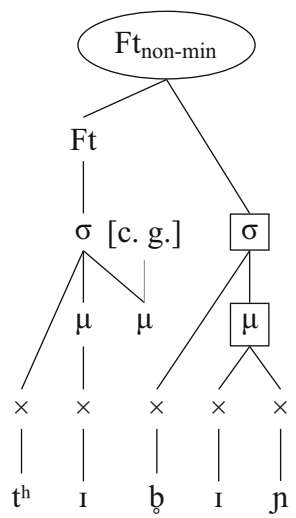

The stem-final consonant [b] fails to project a mora, since its sonority is too low for this in Danish. (This failure is less likely to be due to a ban on ambisyllabic geminates, as shown by the case of sonorant-final stems discussed below). Here, I again assume for concreteness that it is simply resyllabified to become an onset (see Footnote 8 above for discussion). The precise analysis here is immaterial for the present purposes.

There are two important considerations here. First, the circled node in (37) represents a non-minimal foot (cf. Martínez-Paricio 2013; Itô and Mester 2009, 2013 for the use of recursion below the level of the word), since it dominates another foot node. The essence of the analysis is that short-vowel stød appears because the heads of non-minimal feet are required to branch, but in some cases the melodic material provided by the lexicon does not allow for a mora to be projected by a segment. Since repairs such as vowel lengthening or segmental epenthesis are unavailable, the phonology has no choice but to license the mora by associating it directly with a [c.g.] feature. In a sense, short-vowel stød in this case is the mirror image of [h]-epenthesis in Huariapano as analysed by Bennett (2013), where enhancement constraints enforce the insertion of a crucially non-moraic segment, while in Zealand Danish they require the epenthesis of a mora, but not of a segment.

Note that under the standard assumptions of X-bar theory the circled node in (37) is not only non-minimal (dominating another node of the same type) but also maximal (not dominated by another node of the same type). The branching requirement, however, must make reference to a non-minimal rather than a maximal foot. This is because a non-recursive constituent is also maximal under this definition, and requiring (the first syllables of) maximal feet to branch would incorrectly predict short-vowel stød in CV monosyllables like ['n $\left.\left(^{* ?}\right)\right]$ 'now' $(n a ̊)$.

\subsubsection{Non-enclisis and pre-specified metrical structure}

If, as suggested above, short-vowel stød is connected with the presence of enclitic elements, then its lack in the definite forms of $\mathrm{CVC}_{-}$nouns requires an explanation. On the surface, it would appear that CVCən/CVCəð forms should have the same structure, irrespective of whether they are morphologically /CVC-ə $\{\mathrm{n}, ð\} /$ or /CVC_-ə\{n,ð\}/. In this section I argue that the presence of the lexically stored empty 
nucleus in $\mathrm{CVC}_{-}$forms provides a crucial condition for the blocking of cliticization, and consequently the failure of short-vowel stød to appear in superficially similar forms.

The definite singular ['mofən] 'the muff' is represented as follows:

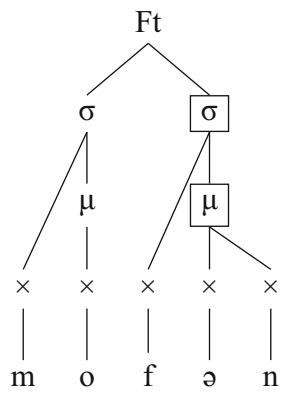

There is no recursion of the foot node in (38), unlike in (37), and thus there is no nonminimal foot that requires a branching head. I suggest the key difference between the two types lies in the status of the syllabic and moraic nodes highlighted by a square. In (37), the nodes that dominate the nucleus in the definite clitic are projected by the clitic itself, because the noun 'tip' lacks the segmental structure to project a second syllable when unsuffixed. Faithfulness constraints prevent the incorporation of new syllables into a minimal foot at the stage when the definite article is inserted. This forces recursion, which incorporates the clitic into a non-minimal foot.

In contrast, the underlying form of the word 'muff' already contains an (empty) syllable node that the definite article can use to receive a prosodic parse; this form was given above as follows:

(24, repeated) Representation of ['mof] 'muff'

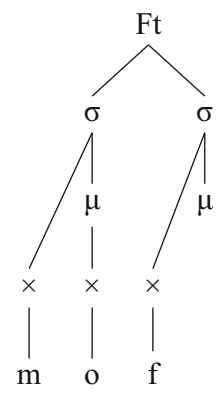

The segmental material in the definite article becomes incorporated into the metrical structure without the need to project a syllable that is not already present in the underlying representation. Since there is no need for recursion, the sole foot node is not non-minimal, and does not enforce a branchingness requirement. 


\subsubsection{The connection between stød and clitics}

As far as I am aware, the proposition that the definite article morphemes are (at least in certain circumstances) clitics cannot be straightforwardly tested by other phonological means. ${ }^{11}$ There is, nevertheless, evidence that the appearance of short-vowel st $\varnothing \mathrm{d}$ is independently connected with encliticization, which provides a further argument for the importance of clitic status.

The phenomenon of 'enclitic stød' is studied in detail by Geist (1976), who focuses on combinations of monosyllables with unstressed forms of personal pronouns (both direct and object cases, and including the inanimate den, det) and the adverbs her 'here' and der 'there', i.e., phrases such as gik her 'went here', slap ham 'let him go (past)', til hende 'to her'. Such unstressed forms appear to fulfil most accepted criteria for clitic status, and there is, as far as I am aware, no evidence for viewing them as affixes.

According to Geist (1976), the host regularly acquires short-vowel stød when the entire group has short-vowel stød basis:
a. ['sla'b ham]
slap ham
'let him go (past)'
b. ['lo?g̊ dn]
luk den!
'close it!'
a. $\quad\left[\right.$ 'the $\left.\mathrm{t}^{\mathrm{d}} \mathrm{dn}\right]$
til den
'to it'
b. ['m $\varepsilon^{?}$ ham $]$
med ham
'with him'

Geist (1976) explicitly says that such syntagms are not distinct from 'single words', including, crucially, noun-article combinations: example (39b) luk den is not distinct from lugten 'the smell' ['lo? g̊dən]. In other respects, these host-clitic combinations in Zealand Danish also behave like noun-article complexes. For instance, there is no addition of stød to disyllabic words, even with empty nuclei, as in disyllabic han ['stød_] sig 'he stumbled' with no stød (han stødte sig) versus monosyllabic han har ['st $\left.\varnothing^{2} \mathrm{~d}\right]$ sig 'he has stumbled' (han har st $\phi d t$ sig). Similarly, words that are st $\varnothing \mathrm{d}-\mathrm{less}$ in isolation appear with common Danish stød when followed by an enclitic: ['gœe? man]

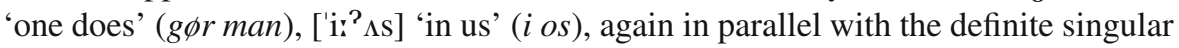
of stød-less nouns.

I conclude that the parallel between what are undoubtedly clitic-host combinations and the definite singular forms of nouns is strong enough to warrant a unified treatment, and since the affixal solution is clearly inappropriate in the former case, we can treat the latter as involving a clitic adjoining to a foot. In addition, 'enclitic stød' provides a strong argument for treating short-vowel stød as a phonological phenomenon. While its

\footnotetext{
11 The syntactic analysis of postposed definite articles is contested: authors such as Faarlund (2009) have argued that the definiteness markers have become affixes, but others point out that their status does not necessarily preclude clitic-like phonological behaviour (e.g., Lahiri et al. 2005b; Börjars and Harries 2008). It might be worth noting that many of the arguments for affixhood hinge on so-called 'double definiteness' (the concurrent presence of a preposed definiteness marker and the bound article in certain constructions), which is not generally characteristic of Danish.
} 
appearance in connection with morphological events such as suffixation of the article or compounding might tempt us to view it as being an exponent of some morphological category, enclitic stød must clearly be part of fully productive postlexical phonological computation, which by necessity involves chunks larger than the morphological word.

Note that an alternative analysis of the 'enclitic stød' facts is available, involving recursive prosodic words rather than feet. I discuss this approach below and show that it is not tenable for independent reasons. It is worth noting here that 'enclitic stød' is triggered not only by cliticization to content words, as in (39), but also when two functional elements come together in a phrase, as in (40). In the former case, it is reasonable to expect the presence of a prosodic word node in the input, which is crucial to the analysis; in the latter case, on the other hand, constructing a prosodic word over a single functional element such as a preposition is difficult to motivate. This still leaves the question of how exactly groups such as those in (40) are prosodified, which I leave open for reasons of space and focus. However, if the constituent involved is the foot rather than the word it stands to reason that the prosodification is driven by metrical considerations and constraints on layering, which do not force the assumption of prosodic words formed over functional elements (see, e.g., Šurkalović 2013 for some discussion, albeit with reference to English).

\subsubsection{OT analysis}

In this section I argue that the distribution of short-vowel stød is determined by the combined effect of constraints that require featural licensing for morae and faithfulness to input metrical structure. Short-vowel stød is parasitic on the creation of a recursive foot. Its appearance is due to a family of constraints which I shall refer to as LICENSE- $\mu$ :

(42) LICENSE- $\mu[\mathrm{Seg}]$ : assign a violation mark for every mora that is not associated with some root node

In most cases, these constraints are satisfied, since most morae are projected by some segment (a vowel or a coda of sufficient sonority). They become more important in situations where a mora is inserted due to top-down requirements rather than being projected 'bottom-up'.

Consider the definite singular of CVC nouns, as in [' $\left.\mathrm{t}^{\mathrm{h}} \mathrm{I}^{\mathrm{P}} \mathrm{b} \mathrm{c} \mathrm{n}\right]$ 'the tip'. It has the following metrical structure. 
(37, repeated)

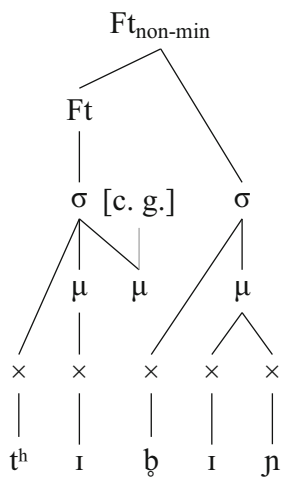

Under this representational system, we need to provide an account for two facts beyond the addition of [c.g.] to the second mora in the first syllable: the appearance of that mora and the construction of the recursive foot. I suggest the following analysis:

(i) Under a clitic analysis of the definite article, the input to phonological computation at the stage where the article is concatenated with the stem contains a fully prosodified form of the stem, complete with a foot node;

(ii) The recursive foot is constructed because faithfulness prohibits the insertion of association lines between a minimal foot (i.e., one that is not dominated by another foot) and a syllable node;

(iii) There is a requirement for initial syllables in recursive structures to be bimoraic.

In concrete OT terms, these requirements can be implemented as follows, respectively:

(i) The input in the computation of [' $\left.\mathrm{t}^{\mathrm{h}} \mathrm{I}^{\mathrm{b}} \mathrm{b} \mathrm{I} \mathrm{I}\right]$ 'the tip' is $/\left(\mathrm{t}^{\mathrm{h}} \mathrm{Ib}\right)_{\mathrm{Ft}} \mathrm{In} /$. In this paper I assume a stratal/cyclic mode of phonological computation (e.g., BermúdezOtero 2011), so that prior to the suffixation of the article the stem has already undergone a cycle of phonological computation, including prosodification and foot construction; ${ }^{12}$

(ii) The insertion of association lines is prohibited by a constraint of the DEPLINK family (Morén 2001): in this case, $\operatorname{DEPLINK}\left(\mathrm{Ft}_{\text {min }}, \sigma\right)$.

(iii) For the sake of the argument, I implement the bimoraicity requirement as a headdependent asymmetry along the lines of Dresher and van der Hulst (1998), using the constraint BRANCHING COMPLEXITY/ $/ \mathrm{Ft}_{\text {non-min }}$, which requires the head of a recursive foot to have more branches than its dependent. This has to dominate DEP- $\mu$, prohibiting the insertion of morae.

\footnotetext{
12 Alternatively, as a reviewer points out, the 'cyclic' misapplication of syllabification could be due to Output-Output correspondence constraints (cf. Krämer 2009: 230-232 for a case of Output-Output faithfulness to metrical structure in Roman Italian). The choice does not appear to have a direct bearing on the key tenets of the analysis.
} 
The construction of the recursive foot requires DEPLINK $\left(\mathrm{Ft}_{\min }, \sigma\right)$ to dominate *RECURSION-Ft, which militates against recursive feet; for the sake of brevity I do not show constraints which ensure that the definite article does project a syllable node.

\begin{tabular}{|c|c|c|}
\hline$/\left(\mathrm{t}^{\mathrm{h}} \mathrm{Ib}\right)_{\mathrm{Ft}} \mathrm{In} /$ & $\operatorname{DepLink}\left(\mathrm{Ft}_{\min }, \sigma\right)$ & $* \mathrm{REC}-\mathrm{Ft}$ \\
\hline a. $\left.\quad\left[\left({ }^{\mathrm{h}} \mathrm{t}_{\mathrm{Ib}} \mathrm{b}_{\mathrm{o}}\right)\right)_{\mathrm{Ft}}\right]$ & $* !$ & \\
\hline b. $\left[\left(\left(\mathrm{t}^{\mathrm{h}} \mathrm{I}^{2}\right)_{\mathrm{Ft}} \mathrm{F}_{\min } \mathrm{b} \mathrm{g}\right)_{\mathrm{Ft}}\right]$ & & $*$ \\
\hline
\end{tabular}

Among the candidates with the recursive foot, the ranking selects one where LICENSE- $\mu$ is satisfied through the attachment of [c.g.] to the second mora. The analysis is shown in (44).

\begin{tabular}{|c|c|c|c|c|c|}
\hline$/\left(\mathrm{t}^{\mathrm{hib}}\right)_{\mathrm{Ft}} \mathrm{In} /$ & BRCOMP-Ft & $\begin{array}{c}\text { DepLinK } \\
(\mathrm{V}, \mu) \\
\end{array}$ & * $\mu[$ bdåg] & LIC- $\mu[\mathrm{F}]$ & $\begin{array}{c}\text { DEP } \\
([\mathrm{c} . \mathrm{g} .])\end{array}$ \\
\hline a. $\quad\left[\left(\left(\mathrm{t}^{\mathrm{h}} \mathrm{I}\right)_{\mathrm{Ft}} \mathrm{b} \mathrm{bI}\right)_{\mathrm{Ft}}\right]$ & $* !$ & 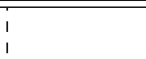 & 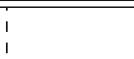 & $\begin{array}{c}1 \\
\vdots\end{array}$ & \\
\hline b. $\quad\left[\left(\left(\mathrm{t}^{\mathrm{h}} \mathrm{i}_{\mu \mu \mu}\right)_{\mathrm{Ft}} \mathrm{bin}\right)_{\mathrm{Ft}}\right]$ & & $* !$ & $\begin{array}{c}1 \\
\vdots \\
\end{array}$ & $\begin{array}{c}1 \\
1 \\
\end{array}$ & \\
\hline c. $\quad\left[\left(\left(\mathrm{t}^{\mathrm{h}} \mathrm{I} \mathrm{b}_{\mu}\right)_{\mathrm{Ft}} \mathrm{b}_{\circ} \mathrm{In}\right)_{\mathrm{Ft}}\right]$ & & $\begin{array}{c}3 \\
\vdots\end{array}$ & $* !$ & $\begin{array}{c}3 \\
\vdots \\
\end{array}$ & \\
\hline d. $\quad\left[\left(\left(\mathrm{t}^{\mathrm{h}} \mathrm{I}(\mu)\right)_{\mathrm{Ft}} \mathrm{bIg}\right)_{\mathrm{Ft}}\right]$ & & 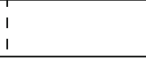 & 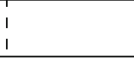 & $* !$ & \\
\hline e. 咹 $\left[\left(\left(\mathrm{t}^{\mathrm{h}} \mathrm{I}^{2} \mu\right)_{\mathrm{Ft}} \mathrm{b} \mathrm{I} \mathrm{I}\right)_{\mathrm{Ft}}\right]$ & & $\begin{array}{c}5 \\
1 \\
\end{array}$ & $\begin{array}{l}1 \\
1 \\
1\end{array}$ & $\begin{array}{l} \\
1\end{array}$ & $*$ \\
\hline
\end{tabular}

Candidate (44a) fails to satisfy BRANCHING COMPLEXITY by not having a heavy initial syllable in the recursive structure. Candidates $(44 b-d)$ do ensure the correct branching asymmetry, but violate other constraints. Candidate (44b), with vowel lengthening, falls foul of a DEPLINK constraint that prohibits vowels from acquiring a mora that they are not associated with in the input (see Morén 2001 for discussion of such cases). Candidate (44c) provides the branching structure using gemination of the stop, but moraic obstruents are generally prohibited in the language due to * $\mu[$ bdo̊ $g$ ]. Finally, candidate (44d) simply inserts a second mora but does not associate it with any melodic material: although it is not obvious how this structure would be phonetically realized, the representational system provides for this possibility; the candidate is eliminated by LICENSE- $\mu[\mathrm{F}]$.

In the case of disyllabic words like /mof_/ 'muff', no violation of *REC-Ft is necessary, since there is no need for the foot to incorporate a syllable that is not already present in the input. This case provides an insight into the connection between the two rankings identified above: the incorporation of the definite article into the preceding foot incurs a violation of $\operatorname{DepLinK}(\mathrm{V}, \mu)$, and the fact that it is allowed in the winning candidate shows the higher ranking of the no-recursion constraint relative to $\operatorname{DEPLinK}(\mathrm{V}, \mu)$ : 
(45)

\begin{tabular}{|c|c|c|c|c|}
\hline$/(\mathrm{mof})_{\mathrm{Ft}} \curvearrowright \mathrm{n} /$ & $\operatorname{DepLink}\left(\mathrm{Ft}_{\min }, \sigma\right)$ & $* \mathrm{ReC}-\mathrm{Ft}$ & $\operatorname{DepLink}(\mathrm{V}, \mu)$ & $\operatorname{DeP}([\mathrm{c} . \mathrm{g}])$. \\
\hline a. $\left[(\text { mofən })_{\mathrm{Ft}}\right]$ & & & $*$ & \\
\hline b. $\quad\left[\left(\left(\mathrm{mo}^{?}\right)_{\mathrm{Ft}} \mathrm{f} ə \mathrm{n}\right)_{\mathrm{Ft}}\right]$ & & $* !$ & & $*$ \\
\hline
\end{tabular}

A final explanandum in this section is the behaviour of sonorant-final words, which are not eligible for short-vowel stød. In isolation, they may or may not bear common Danish st $\varnothing \mathrm{d}:\left[\right.$ [hal $^{\text {? }}$ 'hall' (hal) but [ $\left.\mathrm{t}^{\mathrm{h}} \mathrm{al}\right]$ 'number' (tal). Crucially, the addition of the definite article forces that appearance of stød in the stem: [ $\mathrm{t}^{\mathrm{h}} \mathrm{al}^{\mathrm{P}} \partial$ ð] 'the number' (tallet).

In representational terms, as noted above, I follow the analysis by Basbøll (2003, 2005), who sees common Danish stød as the automatic addition of the laryngeal feature onto any second mora of a syllable, which in Standard Danish can only be projected by a sonorant or a vowel. Consequently, Basbøll (2003, 2005) contends that special provision must be made not for st $\varnothing \mathrm{d}$ on sonorant codas (as in ['hal $\left.{ }^{2}\right]$ ) but for its absence (as in [' $\left.\mathrm{t}^{\mathrm{h}} \mathrm{al}\right]$ ), and analyses the latter as involving lexically specified consonant extrametricality: $/ \mathrm{t}^{\mathrm{h}} \mathrm{a}<\mathrm{l}>/$. Since extrametricality is only available at a word edge, the suffixation of the definite article forces the final sonorant to lose its special status and be parsed as a moraic geminate in line with the behaviour of sonorants in the language generally.

Thus, the explanandum for any theory of short-vowel stød is that any prosodic configuration adduced to explain it must also be compatible with the appearance of common Danish stød in the same context in words of the requisite form. The present analysis fulfils this requirement: under the rankings proposed above, ['t $\mathrm{h}^{\mathrm{al}}{ }^{\mathrm{P}}$ əð] 'the number' also contains a recursive foot, and should thus have a bimoraic initial syllable. In such words, however, the second mora can be provided by the sonorant, since $* \mu[$ son] is ranked relatively low (Morén 2001). The winning candidate has the following structure:

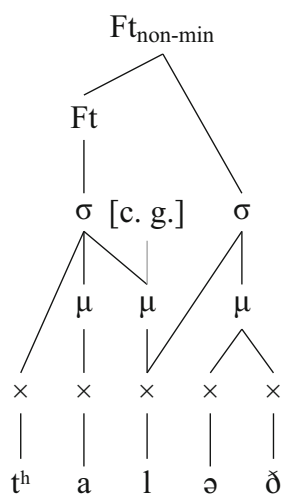

The OT analysis is shown in (47); for reasons of focus, I do not consider in detail the ranking that forces all second morae in a syllable to become associated with st $\varnothing \mathrm{d}$ even when they are otherwise segmentally and featurally licensed, but the relevant 
constraints (notated as STD for convenience, although see below for one possible concrete proposal) clearly outrank DEP([c.g.]). ${ }^{13}$

\begin{tabular}{|c|c|c|c|c|c|}
\hline$/\left(\mathrm{t}^{\mathrm{h}} \mathrm{a}\right)_{\mathrm{Ft}} \mathrm{l} ə \mathrm{~d} /$ & STøD & BRCoMP-Ft & $\operatorname{DEP}([\mathrm{c} . \mathrm{g}])$. & LIC- $\mu[\mathrm{Seg}]$ & $* \mu[$ son $]$ \\
\hline a. $\quad\left[\left(\left(\mathrm{t}^{\mathrm{h}} \mathrm{a}\right)_{\mathrm{Ft}} \mathrm{l} \partial\right)_{\mathrm{Ft}}\right]$ & & $* !$ & & & \\
\hline b. $\left[\left(\left(\mathrm{t}^{\mathrm{h}} \mathrm{al}_{\mu}{ }_{\mu}\right)_{\mathrm{Ft}} \mathrm{l} \mathrm{\gamma}\right)_{\mathrm{Ft}}\right]$ & & & $*$ & & $*$ \\
\hline c. $\quad\left[\left(\left(\left.\mathrm{t}^{\mathrm{h}} \mathrm{a}\right|_{\mu}\right)_{\mathrm{Ft}} l{ }^{\gamma}\right)_{\mathrm{Ft}}\right]$ & $* !$ & & & & $*$ \\
\hline 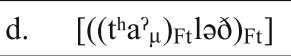 & & & $*$ & $* !$ & \\
\hline
\end{tabular}

Candidate (47a) fails to provide the second mora in the branching structure. Candidate (47c) satisfies the branching requirement by creating an ambisyllabic geminate [1], which projects a mora but lacks stød; this is generally disallowed in Danish. Candidate (47d) has short-vowel stød, in parallel to obstruent-final stems. It ties with the winning candidate on DEP([c.g.]), since both receive some sort of stød; however, candidate (47b) wins, because the second mora is licensed by a segment, a requirement that short-vowel stød fails to satisfy. Thus, the proposed ranking accounts for the behaviour of both short-vowel stød and common Danish stød in clitic constructions. ${ }^{14}$

A final set of ranking arguments involving the constraints discussed in this section involves the underived forms of words such as ['mof_] 'muff'. Above it was suggested that these contain a final empty mora that remains unlicensed either segmentally (e.g., through the insertion of some default vowel) or featurally (through the insertion of [c.g.]). The lack of segmental licensing must be due to some faithfulness constraint dominating LIC- $\mu[\mathrm{Seg}]$. I suggest that this constraint is the positional version of MAX$\mu$ that applies only to morae that head syllabic domains (Beckman 1998); I write this as MAX- $\mu_{\mathrm{Hd}}$. It follows that non-head empty morae may not be preserved, since they are not protected by MAX- $\mu_{\mathrm{Hd}}$; I argue that featurally unlicensed non-head morae are indeed disallowed in Zealand Danish below in Sect. 4.3.

As for the lack of featural licensing, I suggest that, although LIC- $\mu[\mathrm{F}]$ outranks $\operatorname{DEP}([\mathrm{c.g}]$.$) , the candidate ['mof_?] fails because of a general ban on the association$

\footnotetext{
${ }_{13}$ For simplicity's sake, I follow Basbøll (2005) in viewing the sonorant in [' $\mathrm{t}^{\mathrm{h}} \mathrm{al} \mathrm{l}^{\mathrm{p}}$ ð] as a classic flopped geminate, although there is no phonetic length associated with this segment (see Grønnum and Basbøll 2001 for discussion). An alternative analysis would be to assume that the sonorant is crisply captured as a coda, with the following syllable remaining onsetless; see, e.g., Bye and de Lacy (2008) for an analysis of flapping in New Zealand English along these lines.

14 This analysis also provides evidence for choosing the foot rather than the word as the key recursive constituent (cf. Sect. 4.1.3). Briefly, the fact that an extrametrical consonant must be incorporated into the prosodic word under definite article suffixation follows automatically if the stem-article complex is contained within a single (maximal) foot. Moreover, if extrametricality involves adjunction to a prosodic word (cf. Vaux and Wolfe 2010 for discussion), and the recursive constituent requiring branching heads was the word rather than the foot, the analysis in Sect. 4.1 .1 would require words like $/ \mathrm{t}^{\mathrm{h}} \mathrm{a}<\mathrm{l}>/$ 'number' to be represented in the input as $/\left(\left(\mathrm{t}^{\mathrm{h}} \mathrm{a}\right)_{\omega} 1\right)_{\omega} /$. This would be counterfactually expected to surface with short-vowel stød.
} 
of head positions in the syllable with the feature [c.g.]. ${ }^{15}$ This constraint prohibits all morae which head a Danish syllable from bearing [c.g.]. This constraint is generally unviolated in Danish: if we assume that the head mora in the syllable is the leftmost one, its action accounts for the fact that [c.g.] only ever associates to second morae, whether in common Danish or short-vowel stød. ${ }^{16}$ Following de Lacy (2006), I write the constraint as $* \Delta_{\sigma}$ [c.g.] ('assign a violation mark for each head of syllabic domain associated with [c.g.]').

\begin{tabular}{|c|c|c|c|c|c|}
\hline /mof_I & MAX- $\mu_{\mathrm{Hd}}$ & LiC $-\mu[$ Seg $]$ & $* \Delta_{\sigma}$ [c. g.] & LiC- $\mu[\mathrm{F}]$ & $\operatorname{DEP}([$ c. g. $])$ \\
\hline a. ['mof $]$ & & $*$ & & $*$ & \\
\hline b. ['mof] & $* !$ & & & & \\
\hline c. ['mof_'] & & $*$ & $* !$ & & $*$ \\
\hline
\end{tabular}

\subsection{Short-vowel stød and unstressed prefixes}

In this section I analyse another context where short-vowel stød is obligatory, namely that of polysyllabic forms with unstressed prefixes. I show that the appearance of short-vowel stød in this context is driven by the same principles as in the case of definite singulars of CVC nouns. In addition, these forms provide valuable evidence for a generalization that cannot be extracted from the definite singular cases, namely that short-vowel stød may only appear in a non-final syllable. This generalization plays an important role in the analysis of lexical short-vowel stød that follows in Sect. 4.3.

Short-vowel stød is completely disallowed in monosyllables (Sect. 3.2). The requirement for stød to be licensed only in a recursive foot immediately accounts for this distributional gap, since monosyllables lack the segmental content to build such a structure, much as the tonal accent contrast in most varieties of Norwegian and Swedish is neutralized in monosyllables due to the requirement for 'accent 2' to be realized over two syllables.

The behaviour of verbal forms with unstressed prefixes [be-] and [f $\left.\Lambda_{-}-\right]$provides further evidence for the necessity of a following syllable in forms with short-vowel stød. Given the right segmental content in the stem, short-vowel st $\varnothing \mathrm{d}$ is obligatory following these prefixes, but only if another syllable follows: ${ }^{17}$

\footnotetext{
15 Cf. the *PEAK/X constraints in Prince and Smolensky (1993) or, more pertinently, constraints on domain heads in de Lacy (2006).

16 In fact, one possible formalization of the constraint STøD in (47) is the ranking $* \Delta_{\sigma}$ [c.g.] $\gg$ LIC- $\mu[$ c.g.] $\gg$ DEP([c.g.]), with the middle constraint also replacing LIC- $\mu[\mathrm{F}]$. This would force all non-head morae in Danish to bear stød. The difference between Standard Danish and Zealand Danish would then be easily derivable in terms of the ranking of LIC- $\mu[\mathrm{Seg}]$ : in Zealand Danish, its low ranking ensures the possibility of both short-vowel stød and empty morae in words like ['mof_], which are both absent in Standard Danish.

17 See Sect. 5.4 below for the exact representation of non-moraic codas.
} 
(17, repeated)
a. [f $\left.\mathrm{f}^{\prime} \mathrm{p}^{\mathrm{h}} \mathrm{i}^{\mathrm{T}} \mathrm{skəð}\right]$ forpisket
'to whip, past participle'
b. [f ' 'lø'stəlsə]
forlystelse
'entertainment'
c. [be'ny'də]
benytte
'to use, inf.'

If the post-prefix part is monosyllabic, short-vowel stød is impossible, as in all other cases where the short-vowel stød basis is absent:

$$
\text { [f } \Lambda \text { 'slid] forslidt 'tattered' }
$$

The consistently unstressed status of [be-] and [ $\left.\mathrm{f}_{\Lambda^{-}}\right]$suggests that they have some lexical property that influences their prosodic parse. There are a number of options for what that property might be. Basbøll (2005) suggests that these prefixes in Standard Danish have the lexical property of not being included in a minimal stem, and also that they are not specified as bearing a [stress] feature. For Norwegian, where much the same facts hold, Kristoffersen (2000) proposes a cyclic solution, where the prefixes are concatenated with the stem after the application of the main stress rule in the latter. Finally, Riad (2014) analyses the Swedish prefixes as involving subcategorization for a recursive prosodic word. In this section, I argue that the latter approach holds most promise for the Zealand Danish facts.

The proposed representation for a short-vowel stød word with an unstressed prefix is shown in (50). ${ }^{18}$

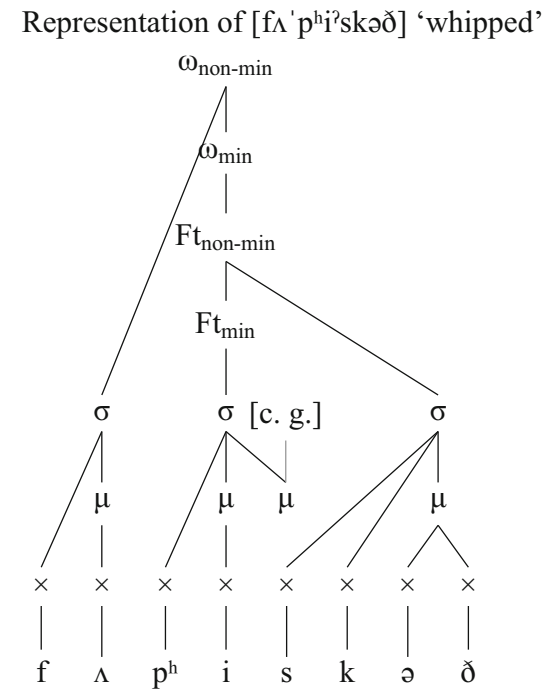

Note that the minimal prosodic word (i.e., the whole form minus the prefix) has exactly the same metrical structure as the noun-definite article combinations discussed in Sect. 4.1, and the appearance of short-vowel stød is driven by the exact same mechanism. The explanandum in this section is why the second syllable in the minimal prosodic word has to be adjoined to a preceding foot rather than being incorporated

\footnotetext{
18 For the sake of the argument, I assume that the final syllable contains a complex onset; see below Sect. 5.4 for more discussion of such structures.
} 
into it. I propose that a consideration of the domain structure of such forms allows us to assimilate them to the enclisis cases discussed above.

It is worth noting that there is a morphosyntactic restriction on the words discussed in this section, since the prefixes be- and for-are generally associated with verbal roots; Ejskjær (1967: 23-24) is explicit about this, saying that a second stressed syllable in a trisyllabic (or longer) word has short-vowel stød "as long as the [initial] unstressed syllable is one of the prefixes be- or for-added to a verbal root" (emphasis mine). ${ }^{19}$

Both the morphosyntactic restriction and the appearance of short-vowel st $\varnothing \mathrm{d}$ are accounted for in a stratal/cyclic model of phonological computation, if the prefixes are required to adjoin to a prosodic word. The domain structure of forms such as [be'ny ${ }^{2}$ də] 'use (infinitive)' is $\llbracket^{\mathcal{W}} \mathcal{L} \llbracket \mathcal{S} \mathcal{L}_{\text {beny }}$ ' $\mathrm{d} \rrbracket \mathrm{e} \rrbracket:$ the innermost domain is reasonably analysed as the stem, whereas the inflectional suffix is a word-level domain. This analysis, incidentally, is compatible with that proposed by Basbøll (2005) on the basis of the behaviour of common Danish stød, where the unstressed prefix and the root cohere to form a domain Basbøll calls MED-STEM, and which can be joined with unproductive suffixes to form a 'minimal word', the innermost domain for stød-manipulating rules. The fact that $b e$ - and for-show idiosyncratic semantics also supports the view of the 'be- + root' complex as a stem-level domain; see Kaisse and McMahon (2011), Bermúdez-Otero (2012) for discussion of the 'stem-level syndrome'. ${ }^{20}$

If the portion /benyd/ is a stem, it is expected to undergo phonological computation, including prosodification (see also Bermúdez-Otero 2012, 2013 for arguments that stem-level constructs are lexically stored with metrical structure, including foot structure). Coupled with the requirement for the prefix /be/ to be adjoined to a prosodic word, the result is that the root must project a monosyllabic foot, as shown in (51).

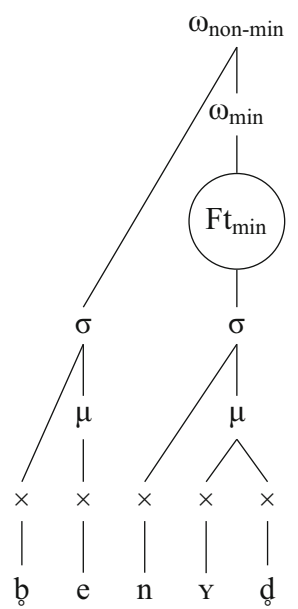

19 ,,[N]år blot den trykløse stavelse er et af præfikserne be- ell. $f_{\Lambda^{-}}$'for' føjet til en verbal rod.“

20 We also find short-vowel stød in deverbal derivatives like forlystelse 'entertainment', which include suffixes that do not fall within Basbøll's 'minimal word' domain, but since they are derived from verbal stems

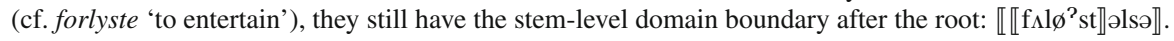


The projection of the foot follows from basic layering assumptions: if the prefix is lexically required to adjoin to a prosodic word, that prosodic word must be projected; but under standard assumptions a prosodic word includes at least one foot.

At later levels, this prosodified input is concatenated with other suffixes, which may or may not be syllabic. When they are syllabic, however, the situation is exactly parallel to that seen with definite clitics in Sect. 4.1.4: a syllable has to be incorporated into an input foot (circled in (51)), which forces the creation of a recursive foot and the satisfaction of asymmetry requirements through short-vowel stød. When there is no additional syllable projected after suffixation, as in [f $\mathrm{f}_{\Lambda}$ 'slid] 'tattered', nothing forces foot recursion, and hence there is no short-vowel stød.

Having established that short-vowel stød is only licensed in a disyllabic recursive foot, we turn to cases where its distribution is less predictable, and where faithfulness must be involved. I argue that the relevant aspect of faithfulness is metrical structure rather than the presence of stød itself.

\subsection{Lexical short-vowel stød}

In the case of morphologically simple words, the distribution of short-vowel stød appears unpredictable, as the following pairs demonstrate:

(7, repeated) Short-vowel stød

$\begin{array}{llll}\text { a. } & \text { ['sta'g̊al] } & \text { stakkel } & \text { 'wretch' } \\ \text { b. } & {\left[\text { ' } \varepsilon^{2} \text { de }\right]} & \text { efter } & \text { 'after' } \\ \text { c. } & {[\text { 'fa'ste }} & \text { faster } & \text { 'aunt' }\end{array}$

(8, repeated) No short-vowel stød

$\begin{array}{llll}\text { a. } & {\left[\text { 'k } \mathrm{k}^{\mathrm{h}} \mathrm{labs}\right]} & \text { klapper } & \text { 'clapper' } \\ \mathrm{b} . & {\left[\mathrm{t}^{\mathrm{h}} \mathrm{eskəl}\right]} & \text { tcerskel } & \text { 'threshold' } \\ \text { c. } & {\left[\mathrm{k}^{\mathrm{h}} \mathrm{a} \text { 'rafəl }\right]} & \text { karaffel } & \text { 'jug' }\end{array}$

In OT, such unpredictability arises when the relevant property (short-vowel stød) is present in underlying representations of some morphemes and reproduced faithfully when present. When the property is absent underlyingly, and when its appearance is not enforced by the computation (as in the cases considered above), it is also absent in surface forms. In terms of constraint ranking, relevant faithfulness constraints must outrank (at least some) markedness constraints. In this section, I argue that the constraints relevant to the preservation of input stød do not necessarily refer to stød itself but rather to metrical structure.

The crucial evidence is provided by underived forms which lack short-vowel stød basis, notably monosyllabic ones. Recall that short-vowel stød is impossible unless the relevant form is at least disyllabic; this indicates that some markedness constraint outranks the faithfulness constraint that requires the preservation of the stød. More specifically, a form such as /bre $\mathrm{d}$ d/, provided by the rich base (McCarthy 2005), cannot surface with short-vowel stød (contrast ['bred] 'wide'), due to the effect of some markedness constraint. 
I suggest that this constraint is LIC- $\mu[\mathrm{Seg}]$, which we already encountered in the analysis of stød, where it forced common Danish stød rather than short-vowel stød where a sonorant coda was available (tableau 47). This constraint must outrank $\operatorname{MAX}([\mathrm{c} . g]$.$) , which demands that instances of [c.g.] present in the input should be$ preserved in the output, and MAX- $\mu$, which could otherwise force the retention of the input mora.

\begin{tabular}{|c|c|c|c|}
\hline & & & \\
\hline & & & \\
\hline a. ['bre? $\left.{ }^{? d}\right]$ & $* !$ & & \\
\hline b. ['bre d] & *! & $*$ & \\
\hline c. $\leftrightarrow$ ['bred] & & $*$ & $*$ \\
\hline
\end{tabular}

Note that this ranking only applies to non-head morae. As discussed above in Sect. 4.1.2, in the case of morae that are the heads of syllables MAX- $\mu_{\mathrm{Hd}}$ must outrank LIC- $\mu[$ Seg], because such unlicensed morae are preserved in disyllables like ['mof_] 'muff' thanks to them being the head of the syllable; this is a classic positional faithfulness effect as discussed by Beckman (1998).

How, then, does lexically determined short-vowel stød surface at all? I suggest that since short-vowel stød in underived forms obeys the same prosodic conditions as that in derived contexts, the same structure that forces its appearance in the latter (i.e., a recursive foot) must also be present in the former, except that in this case it is lexically specified rather than derived by the computation. Thus, the presence of short-vowel stød in a morpheme like ['sta? gəl] 'wretch' is due to the fact that the morpheme is stored with lexical foot structure, namely as $/\left((\mathrm{sta})_{\mathrm{Ft}_{\min }} \mathrm{g} \mathrm{l}_{\mathrm{Ft}} / \mathrm{Ft}\right.$, as opposed to $/ \mathrm{t}^{\mathrm{h}} \varepsilon \mathrm{sk}$ // 'threshold', which is not stored with this sort of recursive structure. For ease of exposition, assume for the moment that the [c.g.] feature is also stored. The correct result obtains under the ranking in (53), where FAITH(Ft) is a shorthand for the constraint or constraints that demand the preservation of input foot structure.

\begin{tabular}{|c|c|c|c|c|c|c|}
\hline$/\left(\left(\mathrm{sta}^{\mathrm{P}}\right)_{\mathrm{Ft}} \stackrel{\mathrm{g}}{\mathrm{g}} \mathrm{l}\right)_{\mathrm{Ft}} /$ & $\mathrm{LiC}-\mu[\mathrm{F}]\rangle$ & FAITH $(\mathrm{Ft})$ & BRCoMp-Ft & $\begin{array}{l}\text { Lic- } \mu \\
{[\mathrm{Seg}]} \\
\end{array}$ & $\begin{array}{c}\text { Max } \\
\text { ([c. g.]) } \\
\end{array}$ & $\mathrm{M}_{\mathrm{AX}-\mu}$ \\
\hline a. $\left[\left(\left(\mathrm{sta}^{2}\right)_{\mathrm{Ft}} \stackrel{\mathrm{g} \partial \mathrm{l}}{ }\right)_{\mathrm{Ft}}\right]$ & & & $\begin{array}{l}\vdots \\
\vdots\end{array}$ & $*$ & & \\
\hline b. $\quad\left[\left(\left(\operatorname{sta} \_\mu\right)_{\mathrm{Ft}} \mathrm{g} \rho \mathrm{l}\right)_{\mathrm{Ft}}\right]$ & $* !$ & & 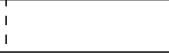 & $*$ & $*$ & \\
\hline c. $\quad\left[\left((\mathrm{sta})_{\mathrm{Ft}} \mathrm{g} \rho \mathrm{l}\right)_{\mathrm{Ft}}\right]$ & 《 & & $* !$ & & $*$ & $*$ \\
\hline d. $\left[(\text { stag̊al })_{\mathrm{Ft}}\right]$ & & $* !$ & 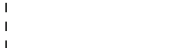 & & $*$ & $*$ \\
\hline
\end{tabular}

The same result is obtained even if the [c.g.] feature is not stored lexically: the correct outcome must contain a recursive foot due to faithfulness, and the ranking shown in (44) then compels the insertion of a [c.g.]-bearing mora.

The crucial role of BRANCHING COMPLEXITY is underscored by the fact that shortvowel st $\varnothing \mathrm{d}$ is absolutely impossible in monosyllables. Technically, if foot recursion 
is allowed by GEN, one could imagine a monosyllabic input with a recursive foot leading to short-vowel stød. However, since the persistence of the segmentally empty mora is enforced by BRANCHING COMPLEXITY, which is vacuously satisfied by a non-branching (i.e., monosyllabic) recursive foot, LIC- $\mu[\mathrm{F}]$ compels the deletion of the stød.

\begin{tabular}{|c|c|c|c|c|}
\hline$/\left(\left(\mathrm{bre}^{2} \mathrm{~d}_{\mathrm{o}}\right)_{\mathrm{Ft}}\right)_{\mathrm{Ft}} /$ & LIC- $\mu[\mathrm{F}] \gg \mathrm{BR}_{\mathrm{R}}$ CомP-Ft & Lic- $\mu[$ Seg $]$ & $\begin{array}{c}\text { Max } \\
([\mathrm{c} . \mathrm{g} .])\end{array}$ & MAX- $\mu$ \\
\hline a. $\quad\left[\left(\left(b_{o} e^{2} d_{0}\right)_{\mathrm{Ft}}\right)_{\mathrm{Ft}}\right]$ & 《 & $* !$ & & \\
\hline b. $\quad\left[\left(\left(\mathrm{bre} \_\mu \mathrm{d}\right)_{\mathrm{Ft}}\right)_{\mathrm{Ft}}\right]$ & $* !$ & * & * & \\
\hline c. $\left[\left((\text { bred })_{\mathrm{Ft}}\right)_{\mathrm{Ft}}\right]$ & $\geqslant$ & & * & $*$ \\
\hline
\end{tabular}

The winning candidate in (54) does have a vacuous recursive foot; given the absence of short-vowel stød in such forms, such structures probably cannot be phonetically implemented in a way that would make them distinct from ordinary monosyllables, so the learner would never be tempted to set up such inputs. What is important here, however, is that this lack of distinction between stød-bearing and stødless monosyllables is not accidental but rather established by the ranking, which correctly rules out short-vowel stød in this prosodic context.

Since the metrical structure is assumed to remain in place throughout the paradigm, the present approach accounts for the tendency of short-vowel stød to not cause paradigmatic alternations: "[short-vowel] stød appears in the definite singular, plural, and indefinite plural of words of the ['sta? g̊̀l] "type" (Ejskjær 1967: 21). ${ }^{21}$

This relative stability of short-vowel stød contrasts with common Danish stød, which shows numerous paradigmatic alternations depending on a number of phonological, morphological, and lexical factors (Basbøll 2005). Under the present account, this difference stems from the different nature of lexical specifications involving the two types of stød. With short-vowel stød, there is little pressure in the phonological grammar to remove the lexically specified recursive foot, which therefore persists under affixation, as does the stød. With common Danish st $\varnothing \mathrm{d}$, the lexical specification, under the analysis by Basbøll (2005), is lack of moraicity, which can be overridden by a variety of factors in different paradigm cells, leading to complex alternations.

Tellingly, if short-vowel stød is present in a morphologically simpler form, it is also present in a derivative. If it is absent in some form in the paradigm, it can also appear in a different cell. In the current analysis, this means that the morphosyntactic properties associated with the stød-bearing form are spelled out by a morpheme that includes the recursive metrical structure. A case in point is the small number of verbs that lack short-vowel stød in the infinitive but acquire it in the present tense, as in ['brø̊﹎] 'to brew' (brygge), present ['brø’o̊ge] (brygger). It is by no means the case that all present-tense forms of monosyllabic verbs acquire short-vowel stød, which shows that there is nothing in the phonological make-up of present-tense forms that requires short-vowel stød. As the process is lexically specific, it is easily formalized

21 „Stød forekommer i bsgl., pl. og bpl. af ord af typen 'stakkel...“ 
as involving a separate conjugational class of verbs that form their present tense by combining a segmental suffix /or/ with a recursive-foot template. A similar account is applicable to the few plurals that show short-vowel stød absent in the singular, as in [es] 'ace', pl. [ $\left.\varepsilon^{2} s e\right]$ 'aces' (es, esser). Most crucially, there do not appear to be cases where a more complex form lacks short-vowel stød but a simpler one shows it. This is accounted for by faithfulness to foot structure persisting under all manner of affixation, which means that phonology is powerless to destroy the context for stød.

\subsection{Stød in compounds}

A final context for short-vowel stød is regularly found in second components of compounds under secondary stress, provided they have the correct structure, i.e., are disyllabic and consist of the correct segments (Ejskjær 1965). (In first elements of compounds, short-vowel stød or its absence is carried over from the simplex form). Its obligatory nature in this context may be accounted for if we assume that compounding involves the imposition of a particular prosodic template, which in the case of Zealand Danish involves the same sort of recursive foot as that seen in lexically stored shortvowel stød. The creation of this template appears to be a part of the morphological operation of compounding rather than a function of the phonological make-up of the stem. The crucial difference between 'compound stød' and other types of short-vowel stød is the fact that the former obligatorily applies to all underlyingly disyllabic words, even if they lack short-vowel stød outside the compound context; contrast (55b) and (55c):
a. ['ask]
aske
'ash'
b. ['askən]
asken
'the ash'
c. $\left[\mathrm{p}^{\mathrm{h}} \Lambda \mathrm{d}, \mathrm{a}^{\mathrm{T}} \mathrm{sk}\right]$
potaske
'potash'

It would thus appear that a solution relying on adjunction to a monosyllabic foot, as in the case of unstressed prefixes (Sect. 4.2), is not directly applicable here. The requirement for a disyllabic, recursive foot in the second element of a compound could be either simply morphological or connected to some kind of templatic requirement active in the conjunction of two separate phonological words: recall that common Danish stød is also required in this context, confirming the obligatory bimoraicity of the initial syllable in these second members of compounds.

Given this connection and the complexity of the data involved, I leave the precise elucidation of the nature of the templatic requirement for the future. ${ }^{22}$ From a phonological perspective, however, if such a templatic requirement is enforced, it creates the correct conditions for the epenthesis of [c.g.] much as in the other cases of short-vowel stød.

\footnotetext{
22 Basbøll (2005) offers an analysis of 'new stød' in Standard Danish based on domain structure and the productivity of relevant suffixes. However, whilst there is a historical connection between 'new stød' in Zealand dialects and the standard language (which does have a Zealand background), it is more regular in the dialects, and hence it appears that a productivity-based account may not be directly transferable.
} 


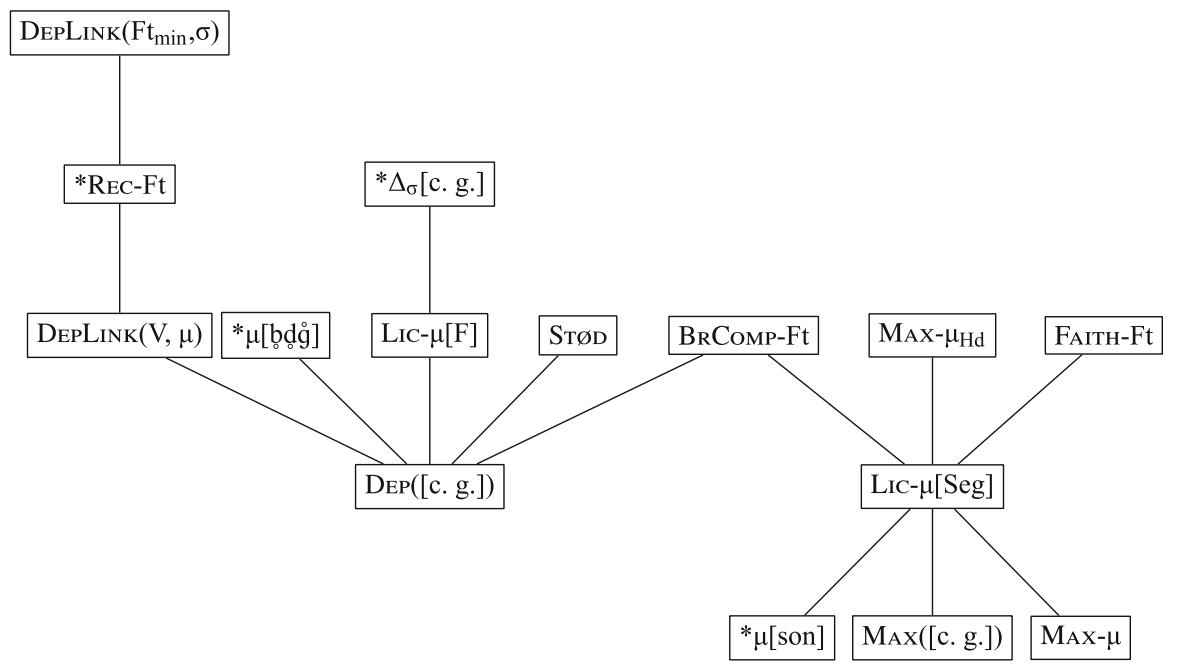

Fig. 1 The complete ranking

This concludes the phonological account of short-vowel stød in Zealand Danish. For the sake of completeness, the full ranking is shown in Fig. 1.

\subsection{Stød and syllable weight}

The representation of short-vowel stød as a marker of syllable weight is not dissimilar to the analysis given by Ejskjær $(1967,1970)$. Working in the structuralist Danish tradition, she sees both short-vowel stød and common Danish stød as the representation of vowel or consonant length: for instance, ['brø: ' $\mathrm{g} \mathrm{e}$ ] 'fractions' is phonemically /bröökər/ and ['brø $\left.{ }^{? g} \mathrm{~g} e\right]$ 'brew (pres.)' is phonemically /brökkər/. Such an analysis is perhaps feasible in purely descriptive terms; I submit, however, that it does not contribute directly to explaining the nature of the phenomenon at hand.

Most obviously, given the lack of an elaborated theory of suprasegmental structure, it is not at all clear why 'consonant length' interacts with top-down prosodic conditions and properties such as the number of syllables in a word. Moraic structure provides a way of tying the internal structure of higher-level constituents with their syntagmatic properties; 'consonant length' does not appear to have any prosodic properties. Therefore, I conclude that the representation used here provides a more motivated account of the properties of short-vowel stød.

\section{Discussion}

In this concluding section I put the proposed account of short-vowel stød into the broader context of 'tone accent' system in Germanic and discuss some theoretical issues arising from the existence of empty morae. 


\subsection{Contrastive metrical structure}

The major point of this paper concerns the interaction of (covert) metrical structure and suprasegmental phonological units such as features and tones. In the case of Zealand Danish, I have proposed that there are two phenomena where the presence of a particular metrical structure determines the presence of particular suprasegmental correlates: 'covert disyllables' (Sect. 3.3) and short-vowel stød itself. In this section I argue that this type of interaction between metrical structure and suprasegmental features is consistent with what can be found elsewhere in Germanic (and beyond).

As noted above in Sect. 3.3, the diachronic process of apocope has not led to a neutralization of the contrast between mono- and disyllables in Zealand and Funen Danish. Since the contrast is expressed through a difference in pitch contours, it has naturally been conceptualized in the literature as a type of 'tonal accent' distinction (Ringgaard 1960a; Larsen 1976; Ejskjær 1990). Such an approach to the accentual consequences of apocope is not unprecedented even within the relatively narrow confines of the North Germanic group: apocope has also led to the creation of 'tonal accent' contrasts in monosyllables in a large area of central Scandinavia (Trøndelag, Norrland and parts of Northern Norway), where the old disyllables bear so-called 'circumflex accent'; see, e.g., Dahlstedt (1962), Liberman (1975), Apalset (1978), Elstad (1979), Dalen (1985), Kristoffersen (1992, 2011a), Almberg (2001) and Lorentz (2008). Another close parallel to the use of pitch to express historical contrasts in syllable counts is found in Danish dialects in East Slesvig (Bjerrum 1949): in these varieties, there is no common Danish stød (and hence no parallel to the Swedish and Norwegian 'accent 1 '/ 'accent 2' distinction), but pitch is used to uphold contrasts such as ring [ ${ }^{1}$ ren] 'ring' versus ringe [ ${ }^{2}$ ren] 'small'.

In generative approaches, tonal accent distinctions have normally been formalized by assuming the presence of lexical tone: a representative example is the analysis of Urban Eastern Norwegian by Kristoffersen (2000). In that variety, 'accent 1' is realized with a $\mathrm{L}+\mathrm{H}$ contour, and 'accent 2' is realized as $\mathrm{H}+\mathrm{LH}$, and under Kristoffersen's analysis 'accent 2' words have a lexical $\mathrm{H}$ tone that 'accent 1' words lack. In principle, this analysis could be extended to Zealand Danish, for instance by assuming a $\mathrm{H}$ tone on old monosyllables and $\mathrm{a}+\mathrm{H}$ contour on old disyllables.

The proposal in Sect. 3.3 to view this distinction as a matter of (lexical) contrast in metrical (more precisely syllabic) structure, if correct, makes Zealand Danish an example of an alternative analysis of tonal accents. Under this alternative 'metrical' analysis tonal accent contrasts are formalized without reference to lexical tone: the tonal differences arise from contrasts in metrical structure and a single phonological grammar that assigns the same tonal melody to different metrical structures in the several accentual classes. This approach has previously been applied to other North Germanic languages by Morén (2003) and Morén-Duolljá (2013), to Franconian tone accents (Köhnlein 2011, 2016; Kehrein 2016; Hermans 2009, 2012; van Oostendorp 2016) and to Scottish Gaelic (Ladefoged 2003; Iosad 2015). In all of these cases, the pitch differences are, at least in some contexts, seen as a matter not so much of the presence or absence of certain tones but rather of the alignment of a single tonal 
melody across different domains, and indeed this 'metrical' approach is consistent with the suggestion by Ladd $(2004,2005)$ that (phonetic) differences in the alignment of pitch peaks are the diachronic source of both 'tonal-accent' systems (as in Swedish and Norwegian, Hebridean Gaelic, or most of Franconian) and prosodic contrasts involving glottalization (as in Danish, Argyll Gaelic, and Cologne Franconian).

With regard to Zealand Danish, an important empirical advantage of this metrical account of tonal differences between mono- and disyllables is the possibility of an explicit connection between these facts and short-vowel stød. Recall that mono- and disyllabic nouns differ in whether they acquire short-vowel st $\varnothing$ d under suffixation of the definite article. Under the account proposed here, the connection between disyllabicity and short-vowel stød is explicit: only monosyllables cannot incorporate the article into the same foot, so recursion occurs and leads to short-vowel stød. It would seem that whatever the precise details of any tonal account, it is difficult to see how the presence of a particular lexical tone should have an influence on the behaviour of the stem under suffixation. The metrical analysis, on the other hand, ties together the tonal pattern of disyllabic words and the syllable-count-related restrictions on short-vowel stød. Therefore, Zealand Danish presents an important argument for the viability of the metrical approach to Germanic tonal accent contrasts. ${ }^{23}$

\subsection{Short-vowel stød and word prosody}

An important aspect of the parallel between short-vowel stød (and, to a certain extent, common Danish stød) as interpreted in this paper and 'metrical' approaches to tonal accents mentioned in the preceding section is the view of 'accent' contrasts as belonging to levels below the prosodic word: stød depends on syllabic and/or foot structure. This view is at odds with the traditional approach to both stød and especially tonal accents as belonging to the word level (cf. the traditional term 'word tones'), and it is reasonable to ask whether losing this insight is worth reinterpreting the accent contrasts as 'lower-level' phenomena. ${ }^{24}$

Here, I discuss two objections to this argument. First, as mentioned in Sect. 3.1, the synchronic (or even diachronic) connection between short-vowel st $\varnothing \mathrm{d}$ and Norwegian and Swedish tonal accents is not particularly strong. In Norwegian and Swedish, there is a strong correlation between the number of syllables in a word, both historically and, at least in some cases, synchronically (although opinions differ as to the exact import of these correlations in the grammar, see in particular Riad 2014: $§ 11.2$ ). Hence, we find robust patterns such as the following Swedish items:

\footnotetext{
23 In addition, if the account proposed here is correct, Zealand Danish shows another case of stored syllable structure, adding to the body of evidence speaking in favour of allowing lexical contrasts in syllabification, or at least in syllable counts; see Vaux (2003), Köhnlein (2016), Ladefoged (2003) and Iosad (2015) for other cases and discussion.

24 I thank two anonymous reviewers for raising many of the issues discussed in this section.
} 
(56) Underlyingly disyllabic stems
a. $\left[{ }^{2}\right.$ 'thak $\left.^{\mathrm{h}} \mathrm{a}: \mathrm{a}\right] \quad$ tacka
'to thank'
b. $\left[{ }^{2} \mathrm{t}^{\mathrm{h}} \mathrm{ak}{ }^{\mathrm{h}}: \mathrm{a}\right] \quad$ tacka!
'thank!'
c. $\quad{ }^{2}$ 'thak $\left.{ }^{\text {h }}: a r\right]$
tackar
'thank, present'

(57) Underlyingly monosyllabic stems, epenthetic $[\varepsilon]$
a. [2'çrs:a]
kyssa
'to kiss'
b. [ ${ }^{1}$ 'çYs: $]$
kyss!
'kiss!'
c. $\left[{ }^{1}\right.$ 'çYs: $\left.\mathrm{er}\right]$
kysser
'kiss, present'

Such alternations are relatively rare in Zealand Danish. As noted in Sect. 4.3 above, whilst such alternations exist, they are definitely a morphologized minority, and the prevalence of short-vowel stød alternations does not appear to relate straightforwardly to the same factors. For instance, with reference to the appearance of short-vowel stød in the present-tense forms of verbs Ejskjær (1967) notes that of 138 forms of a suitable shape recorded in her study, 22 have short-vowel stød and 116 do not, and the class of forms with short-vowel stød is at least diachronically heterogeneous: verbs with short-vowel st $\varnothing \mathrm{d}$ include both historically monosyllabic ones (['sle $\left.{ }^{2} \mathrm{be}\right]$ slipper 'let go, present'; Old Norse sleppr) and historical disyllables (['h/ $\left.{ }^{2} \mathrm{be}\right]$ hopper 'hop, present'; Old Norse hoppar).

Granted, Ejskjær (1967: 40) does suggest that short-vowel stød first arose under circumstances similar to that of common Danish stød: "[T]here can be no doubt that the most satisfying account of the diachronic typology of Zealand short vowel stød is provided by the assumption that the Zealand short vowel stød is the same phenomenon as the common Danish stød, and that the stød originally appears in monosyllables in conditions of alternation". ${ }^{25}$ The parallel is justified by the fact that both short-vowel stød and common Danish stød are marked in disyllabic forms, much like 'accent 1' is marked in disyllabic forms in Norwegian and Swedish (Lahiri et al. 2005a; Wetterlin 2010; Morén-Duolljá 2013). We have also seen in Sect. 4.1.4 that there exists a certain synchronic parallelism between short-vowel and common Danish stød, in that the presence of an enclitic forces both types of stød to appear even if it is absent in a form without an enclitic. The alternation in $\left[\mathrm{t}^{\mathrm{h}} \mathrm{Ib}\right] \sim\left[\mathrm{H}^{\mathrm{h}} \mathrm{I}^{\mathrm{b}} \mathrm{b}_{\mathrm{o}} \mathrm{j}\right]$ parallels that in [' $\left.\mathrm{t}^{\mathrm{h}} \mathrm{al}\right] \sim\left[\mathrm{t}^{\mathrm{h}} \mathrm{al}^{\text {? } ə ð], ~ p r e c i s e l y ~ i n ~ a ~ c o n t e x t ~ t h a t ~ m i r r o r s ~ ' a c c e n t ~} 1\right.$ ' in definite forms of monosyllables in other North Germanic languages: in Swedish $\left[{ }^{1} \mathrm{t}^{\mathrm{h}} \mathrm{Ip^{ \textrm {h } }}\right.$ : $\mathrm{en}$ ] tippen 'the tip' and [ $\left.{ }^{1} \mathrm{t}^{\mathrm{h}} \mathrm{al}: \mathrm{ct}\right]$ tallet 'the number' have accent 1 despite being disyllabic, although in Swedish there is no alternation since the monosyllables also bear accent 1 .

In fact, we could argue that short-vowel stød is more like the tonal accents of Swedish and Norwegian in that, unlike common Danish stød, the contrast is neutralized in monosyllables, whereas common Danish stød is also contrastive in that context. Even this parallel between 'accent 1' and short-vowel stød, however, is not perfect: in Norwegian and Swedish the outcome of neutralization in monosyllables is

\footnotetext{
25 ,,[D]er kan næppe herske nogen tvivl om, at man opnår den mest tilfredsstillende løsning på det sjællandske kortvokalstøds typemæssige diakroni, hvis man antager, at det sjællandske kortvokalstød er et og samme fænomen som fællesdansk stød, og at stødet oprindelig hører til enstavelsesordet under vekslende betingelser."
} 
accent 1 , but in Zealand Danish monosyllables can only have no short-vowel st $\varnothing$ d. I conclude, therefore, that we should not expect short-vowel stød to show significant distributional parallels to the 'accent 1' of Norwegian and Swedish varieties, since the two phenomena do not appear to be particularly closely related diachronically. Some less close parallels might be expected if, as Ejskjær (1967) suggests, short-vowel stød is an analogical development of common Danish stød, which is, in turn, more closely related to the Norwegian and Swedish accents. Depending on the analysis, the two phenomena can be argued to be subject to similar synchronic conditioning, driven by the presence or absence of metrical (particularly foot) structure, whether lexically stored or introduced at earlier cycles: this mechanism is proposed here for short-vowel stød and by Morén-Duolljá (2013) for tonal accents in Swedish. Given the clear differences in patterning — in particular in the systematicity of the relevant alternations outside of the cliticization context - I conclude that pursuing an exactly parallel account of short-vowel stød and Norwegian and Swedish tonal accents is not necessarily fruitful.

A similar argument can be made regarding the status of stød as a 'word accent'. Under the conception of stød pursued by Basbøll (2005) and in this paper, stød is essentially a syllable-level phenomenon. The fact that there appears to be a limit of one stød per (prosodic) word - which justifies a contrast between 'stod words' and 'non-stød' words - arises as an epiphenomenon of the fact that bimoraic syllables - the only structure that is able to support stød - are banned from unstressed position. This latter constraint is quite unremarkable typologically — indeed it is characteristic of most if not all modern North Germanic varieties, although not all of them require stressed syllables to be bimoraic (Kristoffersen 2011b). Given this fact, it is not entirely clear what analytical advantages the notion of a 'word accent' has in the context of stød. One could, in principle, appeal to the traditional notion of 'word tones' and hence a parallel with Norwegian and Swedish, but it is equally unclear whether that notion is particularly useful in those cases either: as intensive research over the last few decades has shown, the Norwegian and Swedish systems submit to an autosegmental analysis that emphasizes the division of labour between lexical and intonational tones, and potentially pre-specified timing relationships. The 'metrical' approach to tonal accents described above expresses this insight particularly clearly, as it allows us to minimize the number of lexical contrasts expressed autosegmentally (whether as tones or as suprasegmental features like [c.g.]) in favour of precisely the kind of sub-word metrical structure that is incompatible with the notion of "word accents'.

I conclude, therefore, that whilst the account of short-vowel stød offered in this paper does not aim to emphasize direct parallels with the 'tonal accents' of Norwegian and Swedish varieties, this does not result in significant loss of generalization.

\subsection{Laryngeal features and metrical structure}

A crucial representational device for the account presented here is the possibility of assigning features that are normally associated with the subsegmental domain to suprasegmental nodes. This proposal stands in contrast to the more widespread view 
whereby prosodic nodes such as morae must be projected by some segmental material. The latter view is, however, not universally accepted, perhaps most notably in frameworks that allow for empty syllable nuclei; see, e.g., Kaye (1990) and Piggott (1991). As for the association of traditionally subsegmental features to suprasegmental nodes, a very similar proposal has been made by Kehrein and Golston (2004) and Golston and Kehrein (2015), who argue that laryngeal features (including, importantly, [constricted glottis]) and vocalic features associate directly to syllabic constituents such as onsets and codas, not to individual segments. Their evidence comes primarily from the cross-linguistic lack of certain contrasts within particular subsyllabic constituents, and they do not consider the possibility that features may associate to segmentally empty prosodic nodes.

I suggest that the approach proposed here, which represents a combination of the two devices independently proposed previously (segmentally empty metrical structure and top-down licensing of 'subsegmental' features) may be fruitful beyond Zealand Danish. A case in point is Icelandic preaspiration and sonorant devoicing (e.g., Jóhannes G. Jónsson 1994; Ringen 1999; Morén 2001; Pétur Helgason 2002; Gunnar Ólafur Hansson 2003; Kristján Árnason 2011). As is well known, 'fortis' stops following a short stressed vowel (traditionally seen to be 'geminate', given the effect of obligatory bimoraicity) are preaspirated:
a. [' $\theta$ ahka]
pakka
'to thank'
b. ['fahta]
fatta
'to understand'
c. ['k $\left.\mathrm{k}^{\mathrm{h}} \mathrm{ohpI}\right]$
koppi
'chamber pot (dat. sg.)'

The consensus in the phonetic and phonological literature is that this preaspiration is a separate segment, based on both its durational properties and its phonological behaviour, particularly the fact that it contributes the obligatory second mora in a stressed syllable (see Kristján Árnason 2011 for an overview of previous approaches). Several authors, notably Jóhannes G. Jónsson (1994) and Ringen (1999), have also sought to connect this preaspiration to sonorant devoicing before underlyingly fortis stops:
a. ['vanta]
vanta
'to need'
b. ['çaolplpa]
hjálpa
'to help'
c. ['verka]
verka
'to process'

I suggest that the device of using segmentally empty nodes associated with a laryngeal feature (in this case, [spread glottis]) provides a unified account of the two phenomena whilst dispensing with some traditional assumptions that might be unnecessary. Consider the case of preaspiration. It is often assumed (see, e.g., Morén 2001) that words such as pakka are lexically stored with fortis geminates $\left(/ \theta \mathrm{ak}_{\mu}^{\mathrm{h}} \mathrm{a} /\right)$ and contrast with words like baggi 'bundle' (/pak $\mathrm{par}_{\mu} \mathrm{I}$, surface ['pakir]), with a short vowel (and another moraic stop) and words like fata 'barrel' ([fait $\left.\left.{ }^{\mathrm{h}}\right) \mathrm{a}\right]$, with the presence of aspiration depending on dialect), stored with a short vowel that undergoes lengthening (with neutralization of the laryngeal contrast outside the stressed syllable). 
These accounts suffer from an important shortcoming, especially given an Optimality Theoretic perspective: they fail to consider the full range of possible input candidates, focusing only on $/ \mathrm{CVC}_{\mu} \mathrm{V} /$ and $/ \mathrm{CVCV} /{ }^{26}$ In particular, the input $/ \mathrm{CVC}{ }^{\mathrm{h}} \mathrm{V} /$ is usually considered to correspond to output $\left[\mathrm{CV}: \mathrm{C}\left({ }^{\mathrm{h}}\right) \mathrm{V}\right]$ (presumably following the historical development from Old Norse). The input $/ \mathrm{CV}: \mathrm{C}\left({ }^{\mathrm{h}}\right) \mathrm{V} /$ tends not to be considered, even though the grammar must be able to map it to a licit output. Given the lack of a preference for consonant moraicity over vowel moraicity, there does not seem to be a reason why such inputs should map to anything other than $\left[\mathrm{CV}: \mathrm{C}\left({ }^{\mathrm{h}}\right) \mathrm{V}\right]$.

This has consequences for the analysis of preaspiration. If output $\left[\mathrm{CV}: \mathrm{C}\left({ }^{\mathrm{h}}\right) \mathrm{V}\right]$ is presumed to be faithful (at least as far as moraic structure is concerned), then input $/ \mathrm{CVC}^{\mathrm{h}} \mathrm{V} /$ does not have to undergo vowel lengthening. This means that preaspiration does not have to be restricted to underlyingly moraic fortis stops. Assume the word pakka is stored lexically as $/ \theta \mathrm{ak}^{\mathrm{h}} \mathrm{a} /$, with a short vowel and nonmoraic stop. The fully faithful candidate cannot be optimal, since stressed syllables in Icelandic are obligatorily bimoraic. Assume further that vowel lengthening is prohibited, e.g., due to highly ranked DepLink( $\mu, \mathrm{V})$; see Morén (2001) and Bye and de Lacy (2008) for similar cases. Assume further that, following Ringen (1999) and Morén (2001), moraic fortis stops are ruled out. Entirely parallel to the Danish case, an empty mora is added to the stressed syllable to satisfy the top-down bimoraicity requirement, enabling [spread glottis] associating leftwards to this mora. The representation is sketched in (60).

(60) Icelandic: derivation of [' $\theta$ ahka] from $/ \theta \mathrm{ak}^{\mathrm{h}} \mathrm{a} /$

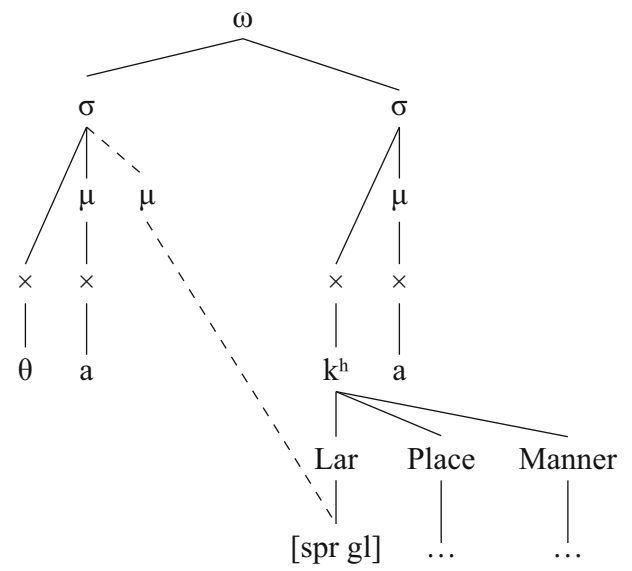

An essentially similar parse is given to an input $/ \theta \mathrm{ak}_{\mu}^{\mathrm{h}} \mathrm{a} /$, with the difference that the second mora in the stressed syllable is not inserted but present in the input (and that the lexically present link between that mora and the stop is deleted). The spreading of [spread glottis] could be accounted for by the constraint LIC- $\mu[\mathrm{F}]$, similar to the

26 There is some discussion of deviant inputs in Gunnar Ólafur Hansson (2003), and see Kristoffersen (2011b) for a detailed consideration of related issues in other North Germanic varieties. 
one used here for short-vowel stød; in view of the existence of sonorant devoicing in Icelandic, however, it seems preferable to suggest that [spread glottis] simply spreads leftward whenever there is a suitable landing site. This gives the entirely parallel representation for sonorant devoicing shown in (61), which is consistent with the approach of Kehrein and Golston (2004), modulo the attachment of the Laryngeal node to the stop rather than the onset.

$$
\text { Icelandic: derivation of ['vanta] }
$$

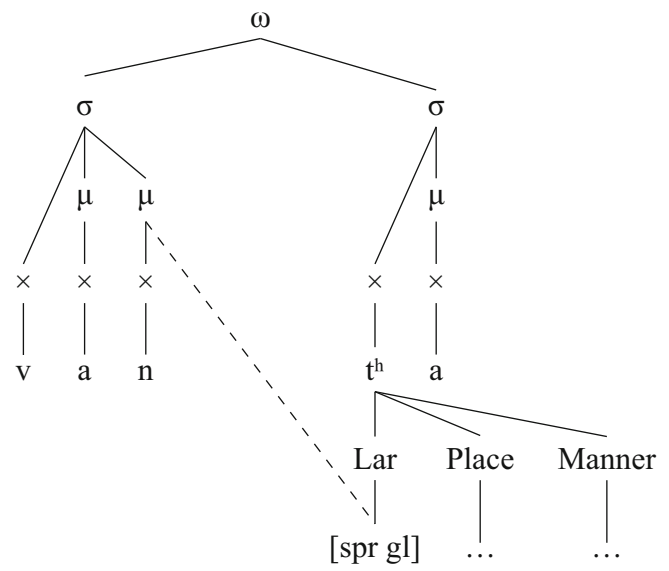

The only difference is that the second mora of the stressed syllable is not inserted due to top-down pressures but projected by the coda through weight-by-position. The mora is therefore licensed. This suggests that there is an independent requirement for [spread glottis] to spread leftward, covering spreading both to empty and segmentally licensed morae. The fact that this account unifies the motivation for preaspiration and sonorant devoicing under the rubric of completely ordinary directional spreading is an advantage over accounts such as that by Ringen (1999), who has to introduce the constraint MULTILINK, which requires that a [spread glottis] feature should be multiply linked in all circumstances and not only when there is a suitable target for spreading (and thus compels the creation of a landing site if it is absent). In this account, the spreading only happens when such a target is present: it is not motivated after unstressed syllables, where there is no second mora, or after long vowels, presumably because a mora dominating a vowel cannot be associated with [spread glottis]. Both of these predictions are correct for Icelandic.

In this section I hope to have shown that the linking of subsegmental features to prosodic nodes is not necessarily an ad hoc theoretical innovation of no use beyond accounting for Zealand Danish; on the contrary, it provides viable analyses of unrelated patterns in other languages. It would, in particular, be an intriguing possibility that a similar representation could be involved in another phenomenon combining stød and short vowels, namely the 'West Jutland stød' (Ringgaard 1960b), which has been argued to be cognate with Icelandic preaspiration (e.g., Pedersen 1912; Page 1997; 
Gunnar Ólafur Hansson 2001; Kusmenko 2008). ${ }^{27}$ I leave further exploration of this phenomenon for the future. ${ }^{28}$

\subsection{Submoraic structure}

One issue that is potentially raised by the proposal of segmentally empty morae is the representation of non-weight-bearing codas. Consider a word or word-clitic combi-

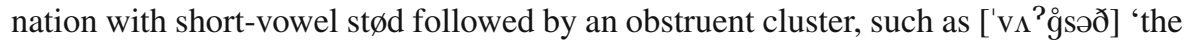
wax' (vokset) or [lo?g̊dn] 'close it!' (luk den). What is the precise syllabic parse of the postvocalic consonant? It seems implausible that the first syllable should be open ([.'v ${ }^{\text {? } . g ̊ s ə ð .]) . ~ O n e ~ o p t i o n ~ f r e q u e n t l y ~ s e e n ~ i n ~ t h e ~ l i t e r a t u r e ~ t o ~ d e a l ~ w i t h ~ c o n s o n a n t s ~ t h a t ~}$ do not contribute to syllable weight (i.e., do not project their own mora) is to adjoin them to the preceding mora; see in particular Broselow et al. (1997). However, it is not immediately obvious how this could be implemented if the preceding mora is empty.

I suggest that a possible solution (again) involves recursion of prosodic constituents. Just as adjunction to a foot and to a prosodic word involves the projection of a recursive word or foot, so adjunction to a mora should also involve recursion. In this case, a

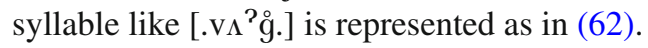

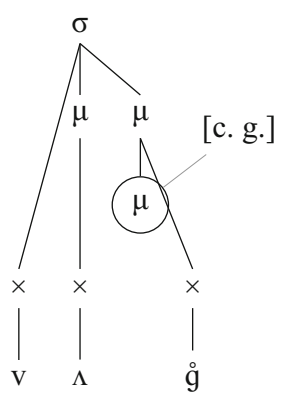

Here, the empty (circled) node is the head of the moraic domain; it is a reasonable suggestion that constraints such as * $\mu[$ bdo̊] (cf. de Lacy (2006), where such constraints are also reinvented in terms of moraic domain heads) and LIC- $\mu$ should really be targeting domain heads rather than simply moraic nodes.

Recursion of subsyllabic constituents has not frequently been proposed in the literature, but such proposals do exist, cf. Hayes (1995) and Karinš̌ (1996) for morae and Smith (1999) for syllables. Since recursion as a representational device is often

\footnotetext{
27 In fact Kusmenko (2008: 137-138) suggests a possible historical connection between preaspiration and the Zealand type of short-vowel stød, although he acknowledges that the distribution of the two is far from parallel.

28 Note that I am not suggesting that, for instance, all cases of preaspiration (e.g., in languages such as Scottish Gaelic) are to be accounted for in this way. For instance, Northern Sami as analysed by Bals et al. (2012) shows a variety of 'segmentalized preaspiration' superficially similar to the Icelandic one, but the [h] segment produced in this process does not necessarily consist of just a [spread glottis] feature. This is because it patterns with continuants in triggering a process of vowel lengthening, and thus may share some other feature with them.
} 
used to implement adjunction above the level of the syllable, I would suggest that we should not entirely discount the possibility of recursion also below the syllabic level. If this possibility is left open, then closed syllables with short-vowel stød can be accommodated in the present model.

In fact, it can be argued that some version of submoraic branching is necessary under the model of moraicity in Danish adopted by Basbøll (2005) and in this paper. Specifically, as Itô and Mester (2015) point out, the assumption that only sonorants project morae in coda position, whilst not unusual typologically (Zec 1988; Morén 2001) and potentially consistent with the behaviour of stød, can be problematic in view of the fact that the stress system of Danish is quantity-sensitive. In Standard Danish, syllables closed by obstruents behave as if they were 'monomoraic' for the purposes of stød but nevertheless attract stress, as in, e.g., kalif [ $\mathrm{k}^{\mathrm{h}} \mathrm{a}$ 'lif] 'caliph' (stress on rightmost closed syllable), parallel to vikar [vi' $\mathrm{k}^{\mathrm{h}} \mathrm{a}_{\mathrm{i}}$ '] 'vicar'. An alternative analysis could assume consistent weight-by-position to account for the behaviour of stress but restrict stød to sonorant moras. Typological parallels for such an analysis can be found in Latvian (Kariňš 1996) and Flekkefjord Norwegian (Hognestad 2007), where stressed syllables are obligatorily bimoraic (at least in some contexts) but neutralize tonal accent contrasts when the second mora is not sonorous enough. ${ }^{29}$ This may be a plausible account, although it does raise some questions: for instance, whilst there is a sound phonetic rationale for the restriction on tonal elements in low-sonority codas, it is less obvious why glottalization would be subject to similar restrictions. ${ }^{30}$

However, whilst I cannot offer a full account of Danish stress in this paper, it may be worth noting that submoraic structure does provide a potential way of capturing the generalization. Specifically, if nonmoraic codas are represented, as throughout this paper, via adjunction, whether to a segmentally projected vocalic mora (as in (51)) or to an empty one as in (62), the relevant mora is still branching. Asymmetries such as the attraction of stress to heavy syllables can also be thought of as branching, or more generally complexity asymmetries (see in particular Dresher and van der Hulst 1998). If the placement of stress can refer to the structure of the head mora in the word, quantity-sensitivity may be potentially due to a restriction that prevents the head of the prosodic word from having fewer branches than a non-head. I leave the full investigation of these issues for future work, however.

\subsection{Features or concurrent segments?}

A final issue is worth discussing with regard to the key representational proposal of this paper, namely the formalization of stød as a feature attaching to a prosodic node. The crucial aspect of this definition is that stød should not be identified with a glottal stop segment, i.e., a representation involving the feature [c.g.] dominated by what many versions of non-linear phonology call the root node. This distinction is important for

\footnotetext{
29 In fact, Hognestad (2007) suggests that a system like that of Flekkefjord Norwegian offers a plausible historical 'missing link' between Norwegian and Swedish tonal accents and Danish stød.

30 Indeed, glottalization may be preferentially associated with low-sonority postvocalic segments in languages such as English or West Jutland Danish.
} 
the analysis, since featural and segmental licensing of morae are assumed to be distinct in Zealand Danish.

A possible alternative analysis sees short-vowel stød as involving simple insertion of a [?] segment to satisfy stress-to-weight requirements. An immediate objection to this analysis is that it breaks the representational unity of short-vowel and common Danish stød: if syllables with short-vowel st $\varnothing \mathrm{d}$ have a [?] coda, then, for instance, under standard assumptions an open syllable with a long vowel and stød cannot contain a coda. Technically, it would be possible to propose a representation along the lines of (63):

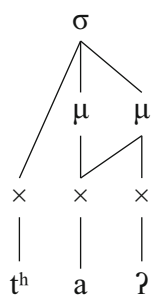

Such a solution, however, does not appear to be much more than a technical fudge, quite apart from the fact that such representations are usually assumed to correspond to surface strings of the form [ $\mathrm{t}^{\mathrm{h}} \mathrm{a}$ :?] (e.g., Bals et al. 2012). More seriously, note how in (63) the root nodes corresponding to [a] and [?] (i.e., the stød) stand in a crisp precedence relation. This goes against a basic result of the phonetic study of stød (Fischer-Jørgensen 1989) by ignoring the fundamental simultaneity of the glottalization and vocalic articulation in stød-bearing syllables.

The simultaneity could be incorporated into an analysis of stød as a glottal stop 'phoneme' by adopting the proposal of Bradfield (2014), who suggests that segments can be not only linearly ordered (as in (63)) but also concurrent. ${ }^{31}$ Concretely, Bradfield (2014) proposes that certain portions of the phonological output may represent the simultaneous realization of more than one segment otherwise available in the language, represented by means of the operator $\otimes$. In this case, short-vowel st $\varnothing \mathrm{d}$ is represented simply as the insertion of a glottal stop: [ $\mathrm{t}^{\mathrm{h}} \mathrm{a}$ ] . Common Danish stød, on the other hand, can be represented using concurrent segments, especially obviously in the case of a sonorant coda: forms like [hal'] 'hall' would then more precisely be [ha $\{1 \otimes 2\}]$.

The problem with this analysis, of course, is that [?] is not usually assumed to be a 'phoneme' of Danish. This problem is especially acute for Standard Danish, where there is no short-vowel st $\varnothing$ d. For varieties with short-vowel st $\varnothing$ d, it could be assumed that underived forms with unpredictable stød like ['sta $\left.{ }^{\text {? }} \mathrm{g} ə \mathrm{l}\right]$ 'wretch' exemplify the phoneme / $/$ /, but Standard Danish, of course, lacks such forms, meaning that $/ \mathrm{R} / \mathrm{can}$ only appear concurrently with another phoneme.

Nevertheless, accepting the existence of a /?/ phoneme in Zealand Danish on the strength of examples like ['sta? 9 gl] does not immediately resolve the issue of why stød appears in predictable phonological environments such as the definite singular

31 See also Ladd (2014: ch. 1) for a similar proposal. 
of CVC nouns. The analysis presumably should follow the lines of Sect. 4.1, with the difference that the mora is licensed segmentally rather than purely featurally. The vast majority of the points made in the present paper with respect to the relationship between metrical structure and stød will therefore remain intact. Given the disadvantages of this account for a unified analysis of the two types of stød, I conclude that while a concurrent-segment approach to stød cannot be decisively ruled out, the account proposed in Sect. 4 still has nontrivial advantages.

\section{Conclusion}

In this paper I have proposed a phonological analysis of the phenomenon of 'shortvowel stød' in the traditional Danish dialects of Zealand. I have argued that its distribution is best understood if we view it as a consequence of top-down prosodic conditioning, whereby certain prosodic categories are required to branch even if the underlying segmental material is insufficient to provide the underpinning for the necessary structures. Short-vowel stød then emerges as a way of featurally licensing the morae inserted by the computation due to this top-down pressure. In representational terms, the understanding of stød as a feature-like (rather than tonal) entity associated to the second mora of a heavy syllable has been argued for in much relevant work, most recently in Grønnum et al. (2013): the difference between ‘common Danish' and 'short-vowel' stød boils down to whether this second mora is projected by segmental material or inserted due to top-down requirements.

The proposal allows us to not only account for the distribution of short-vowel stød in Zealand Danish but also place this phenomenon into its proper cross-linguistic context. Short-vowel stød is not merely a matter of some lexical specification of a particular laryngeal feature: it represents the outcome of interaction between local conditions on prosodic well-formedness and global processes that assign suprasegmental features. This type of interaction has been argued to result in a particular type of 'tonal accent' system observed in Germanic and elsewhere. It is also noteworthy that the representational apparatus proposed for short-vowel stød can also be used for common Danish stød. The appeal to (partly lexically stored) metrical structure in accounting for both stød and Swedish and Norwegian tonal accent allows us to bring out the similarities between the two phenomena. Coupled with recent work arguing for a unified prosodic conditioning of stød and Swedish and Norwegian 'accent 1' (Lahiri et al. 2005a; Wetterlin 2010; Morén 2003; Morén-Duolljá 2013), the present paper opens the way to a better understanding of the synchronic similarities between the systems despite the superficial differences in implementation, and without appeals to stød as an essentially tonal phenomenon, which Grønnum et al. (2013) argue to be unwarranted.

More generally, the proposal in this paper shows the importance of taking seriously the possibilities inherent in current representational theory. Although devices such as empty morae, prosodic adjunction via recursion at all levels of the hierarchy, lexically stored syllabic structure, and direct association of features to prosodic nodes are rarely discussed as viable representational options, they are certainly logical possibilities, and if they are to be excluded, it is desirable that this should be done on strong conceptual 
and/or empirical grounds. In this paper I have shown that these possibilities can in fact be fruitfully exploited in the analysis of phonological phenomena, and therefore that they should perhaps be taken more seriously by analysts.

Acknowledgments Portions of this paper and related work were presented at the 15th Teangeolaíocht na Gaeilge / Cànanachas na Gàidhlig / The Linguistics of the Gaelic Languages conference (University College Dublin) and the 21st Manchester Phonology Meeting (University of Manchester). Thanks to the audience at these events for questions and discussion, in particular Ricardo Bermúdez-Otero, Karthik Durvasula, Claire Nance, Roibeard Ó Maolalaigh, and Iwan Wmffre. I also owe a debt of gratitude to Björn Köhnlein and Bob Ladd for discussion of many points raised in the paper and Peter Ackema for help with morphosyntactic matters. Three anonymous reviewers for JCGL and the editor Susi Wurmbrand have made numerous suggestions that have led to significant improvements in content and presentation. All errors and shortcomings remain entirely mine.

Open Access This article is distributed under the terms of the Creative Commons Attribution 4.0 International License (http://creativecommons.org/licenses/by/4.0/), which permits unrestricted use, distribution, and reproduction in any medium, provided you give appropriate credit to the original author(s) and the source, provide a link to the Creative Commons license, and indicate if changes were made.

\section{References}

Almberg, Jørn. 2001. The circumflex tone in a Norwegian dialect. In Nordic prosody: Proceedings of the VIIIth conference, Trondheim 2000, eds. Wim van Dommelen and Thorstein Fretheim, 19-28. Frankfurt: Peter Lang.

Andersen, Poul. 1958. Fonemsystemet i фstfynsk. På grundlag af dialekten i Revninge sogn. (Udvalg for folkemaals publikationer. Serie A 14). København: J. H. Schultz forlag.

Apalset, Asbjørg. 1978. Apokope og circumfleks i Leksvikmålet. In På leit etter ord: Heidersskrifttil Inger Frøyset, ed. Ingeborg Hoff, 11-26. Oslo, Bergen, Troms $\emptyset$ : Universitetsforlaget.

Avery, Peter, and William J. Idsardi. 2001. Laryngeal dimensions, completion, and enhancement. In Distinctive feature theory, ed. T. Alan Hall (Phonetics and Phonology 2), 41-71. Berlin: Mouton de Gruyter.

Bals Baal, Berit Anne, David Odden, and Curt Rice. 2012. An analysis of North Saami gradation. Phonology 29(2): 165-212.

Basbøll, Hans. 2003. Prosody, productivity and word structure: The stød pattern of Modern Danish. Nordic Journal of Linguistics 26(1): 5-44.

Basbøll, Hans. 2005. The phonology of Danish. Oxford: Oxford University Press.

Beckman, Jill. 1998. Positional faithfulness. Ph.D. dissertation, University of Massachusetts, Amherst.

Bennett, Ryan. 2012. Foot-conditioned phonotactics and prosodic constituency. Ph.D. dissertation, University of California, Santa Cruz.

Bennett, Ryan. 2013. The uniqueness of metrical structure: Rhythmic phonotactics in Huariapano. Phonology 30(3): 355-398.

Bermúdez-Otero, Ricardo. 2011. Cyclicity. In The Blackwell companion to phonology, eds. Marc van Oostendorp, Colin J. Ewen, Elizabeth Hume, and Keren Rice, vol. 4, 2019-2048. Oxford: Blackwell Publishing.

Bermúdez-Otero, Ricardo. 2012. The architecture of grammar and the division of labour in exponence. In The phonology and morphology of exponence: The state of the art, ed. Jochen Trommer (Oxford Studies in Theoretical Linguistics 41), 8-83. Oxford: Oxford University Press.

Bermúdez-Otero, Ricardo. 2013. The Spanish lexicon stores stems with stem vowels, not roots with inflectional class features. Probus 25(1): 3-103.

Bjerrum, Marie. 1949. Felstedmaalets tonale Accenter. Århus: Universitetsforlaget.

Börjars, Kersti, and Pauline Harries. 2008. The clitic-affix distinction, historical change, and Scandinavian bound definiteness marking. Journal of Germanic Linguistics 20(4): 289-350.

Bradfield, Julian. 2014. Clicks, concurrency and Khoisan. Phonology 31(1): 1-49.

Bradshaw, Mary. 1999. A cross-linguistic study of consonant-tone interaction. Ph.D. dissertation, The Ohio State University. 
Broselow, Ellen, Su-I Chen, and Marie Huffman. 1997. Syllable weight: Convergence of phonology and phonetics. Phonology 14(1): 47-82.

Bye, Patrik, and Paul de Lacy. 2008. Metrical influences on fortition and lenition. In Lenition and fortition, eds. Joaquim Brandão de Carvalho, Tobias Scheer, and Philippe Ségéral (Studies in Generative Grammar 99), 173-206. Berlin: Mouton de Gruyter.

Caballero, Gabriela. 2011. Morphologically conditioned stress assignment in Choguita Rarámuri. Linguistics 49(4): 749-790.

Clements, G. Nick, Alexis Michaud, and Cédric Patin. 2010. Do we need tone features? In Tones and features: Phonetic and phonological perspectives, eds. John A. Goldsmith, Elizabeth Hume, and W. Leo Wetzels (Studies in Generative Grammar 107), 3-24. Berlin: De Gruyter.

Dahlstedt, Karl-Hampus. 1962. Det svenska vilhelminamålet: Språkgeografiska studier över ett norrländkst nybyggarmål och dess granndialekter. Del 2: Kvantitet. Apokope (Skrifter utgivna genom Landsmålsoch folkminnearkivet i Uppsala. A: Folkmål 7.2). Uppsala: Almqvist \& Wiksell.

Dalen, Arnold. 1985. Skognamålet. Ein fonologisk analyse. Oslo: Novus.

Dalton, Martha, and Ailbhe Ní Chasaide. 2005. Tonal alignment in Irish dialects. Language and Speech 48(4): 441-464.

de Lacy, Paul. 2006. Markedness: Reduction and preservation in phonology. Cambridge: Cambridge University Press.

Dresher, B. Elan, and Aditi Lahiri. 1991. The Germanic foot: Metrical coherence in Old English. Linguistic Inquiry 22(2): 251-286.

Dresher, B. Elan, and Harry van der Hulst. 1998. Head-dependent asymmetries in phonology: Visibility and complexity. Phonology 15(3): 317-352.

Ejskjær, Inger. 1965. Stød i andet sammensætningsled i typen fortis-semifortis i danske ømål. Acta Philologica Scandinavica 27(1-2): 19-67.

Ejskjær, Inger. 1967. Kortvokalstødet i sjallandsk (Udvalg for folkemaals publikationer. Serie A 22). København: Akademisk forlag.

Ejskjær, Inger. 1970. Fonemsystemet $i$ фstsjallandsk. På grundlag af dialekten i Strøby sogn (Udvalg for folkemaals publikationer. Serie A 24). København: Akademisk forlag.

Ejskjær, Inger. 1990. Stød and pitch accents in the Danish dialects. Acta Linguistica Hafniensia 22(1): 49-75.

Ejskjær, Inger. 2006. Glottal stop (stød, parasitic plosive) and (distinctive) tonal accents in the Danish dialects. In Germanic tone accents: Proceedings of the First International Workshop on Franconian Tone Accents, Leiden, 13-14 June 2003, ed. Michiel de Vaan (Beihefte zur Zeitschrift für Dialektologie und Linguistik 131), 15-24. Stuttgart: Franz Steiner Verlag.

Elstad, Kåre. 1979. Det nordnorske circumflekstonemet. In Nordic prosody, eds. Eva Gårding, Gösta Bruce, and Robert Bannert (Travaux de l'Institut de linguistique de Lund 13), 165-174. Lund: Gleerup.

Faarlund, Jan Terje. 2009. On the history of definiteness marking in Scandinavian. Journal of Linguistics 45(3): 617-639.

Fischer-Jørgensen, Eli. 1989. Phonetic analysis of the stød in Standard Danish. Phonetica 46(1): 1-59.

Geist, Hanne Louise. 1976. Enklitisk stød i sjællandsk. In Studier i dansk dialektologi og sproghistorie tilegnede Poul Andersen, eds. Kristian Hald, Christian Lisse, and John Kousgård Sørensen, 91-100. København: Akademisk forlag.

Golston, Chris, and Wolfgang Kehrein. 2015. A prosodic theory of vocalic contrasts. In The segment in phonology and phonetics, eds. Eric Raimy and Charles Cairns, 65-102. Malden, MA: Wiley.

Grønnum, Nina. 1998. Intonation in Danish. In Intonation systems: A survey of twenty languages, eds. Daniel Hirst and Albert Di Cristo, 131-151. Cambridge: Cambridge University Press.

Grønnum, Nina, and Hans Basbø1l. 2001. Consonant length, stød and morae in Standard Danish. Phonetica 58(4): 230-253.

Grønnum, Nina, Miguel Vazquez-Larruscaín, and Hans Basbøll. 2013. Danish stød: laryngealization or tone. Phonetica 70(1-2): 66-92.

Gunnar Ólafur Hansson. 2001. Remains of a submerged continent: Preaspiration in the languages of Northwest Europe. In Historical linguistics 1999: Selected papers from the 14th International Conference on Historical Linguistics, Vancouver, 9-13 August 1999, ed. Laurel J. Brinton (Current Issues in Linguistic Theory 215), 157-173. Amsterdam: John Benjamins.

Gunnar Ólafur Hansson. 2003. Laryngeal licensing and laryngeal neutralization in Faroese and Icelandic. Nordic Journal of Linguistics 26(1): 45-79. 
Halle, Morris, and Kenneth Stevens. 1971. A note on laryngeal features. In Quarterly progress report, Research Laboratory of Electronics, vol. 101, 198-211. Cambridge, MA.

Hansen, Aage. 1943. St $\phi$ det $i$ dansk (Det Kongelige Danske Videnskabernes Selskab. Historisk- Filologiske Meddelelser 29:5) København: Ejnar Munksgaard.

Hansen, Aage. 1962. Den lydlige udviklingen i dansk fra ca. 1300 til nutiden, Vol. 1: Vokalismen. København: G. E. C. Gads forlag.

Harris, John. 2012. Wide-domain $r$-effects in English. Journal of Linguistics 49(2): 329-365.

Hayes, Bruce. 1995. Metrical stress theory: Principles and case studies. Chicago: University of Chicago Press.

Hermans, Ben. 2009. The phonological structure of the Limburg tonal accents. In Strength relations in phonology, eds. Kuniya Nasukawa and Phillip Backley (Studies in Generative Grammar 103), 317372. Berlin: Mouton de Gruyter.

Hermans, Ben. 2012. The phonological representation of the Limburgian tonal accents. In Phonological explorations: Empirical, theoretical and diachronic issues, eds. Bert Botma, and Roland Noske, 223240. Berlin: De Gruyter.

Hognestad, Jan K. 2007. Tonelag i Flekkefjord bymål. Norsk lingvistisk tidsskrift 25(1): 57-88.

Honeybone, Patrick. 2005. Diachronic evidence in segmental phonology: The case of obstruent laryngeal specification. In The internal organization of phonological segments, eds. Marc van Oostendorp and Jeroen van de Weijer (Studies in Generative Grammar 77), 319-354. Berlin: Mouton de Gruyter.

Hsu, Chai-Shune K. 1998. Voicing underspecification in Taiwanese word-final consonants. UCLA Working Papers in Phonetics 90: 90-105.

Hutters, Birgit. 1985. Vocal fold adjustments in aspirated and unaspirated stops in Danish. Phonetica 42(1): $1-24$.

Hyman, Larry M. 2010. Do tones have features? In Tones and features: Phonetic and phonological perspectives, eds. John A. Goldsmith, Elizabeth Hume, and W. Leo Wetzels (Studies in Generative Grammar 107), 50-80. Berlin: De Gruyter.

Iosad, Pavel. 2015. 'Pitch accent' and prosodic structure in Scottish Gaelic: Reassessing the role of contact. In New trends in Nordic and general linguistics, eds. Martin Hilpert, Janet Duke, Christine Mertzlufft, Jan-Ola Östman, and Michael Rießler, 28-54. Berlin: Mouton de Gruyter.

Itô, Junko, and Armin Mester. 1997. Stø?det i dansk. Handout, Scandinavian Summer School in Generative Phonology, Hvalfjarðarströnd.

Itô, Junko, and Armin Mester. 2009. The onset of the prosodic word. In Phonological argumentation: Essays on evidence and motivation, ed. Steve Parker (Advances in Optimality Theory 5), 227-260. London: Equinox.

Itô, Junko, and Armin Mester. 2013. Prosodic subcategories in Japanese. Lingua 124: 20-40.

Itô, Junko, and Armin Mester. 2015. The perfect prosodic word in Danish. Nordic Journal of Linguistics 38(1): 5-36.

Iverson, Gregory K., and Joseph C. Salmons. 1995. Aspiration and laryngeal representation in Germanic. Phonology 12(3): 369-396.

Jansen, Wouter. 2004. Laryngeal contrast and phonetic voicing: A Laboratory Phonology approach to English, Hungarian and Dutch. Ph.D. dissertation, University of Groningen.

Jensen, John T. 2000. Against ambisyllabicity. Phonology. 17(2): 187-235.

Jessen, Michael, and Catherine Ringen. 2002. Laryngeal features in German. Phonology 19(2): 189-218.

Jóhannes G. Jónsson. 1994. The feature [asp] in Icelandic phonology. Studia Linguistica 48(1): $28-45$.

Kager, René, and Violeta Martínez-Paricio. 2014. Antepenultimate mora effects: Typology and representation. Presentation at the Workshop on Word Stress and Accent, Leiden University.

Kaisse, Ellen M., and April McMahon. 2011. Lexical Phonology and the lexical syndrome. In The Blackwell companion to phonology, ed. Marc van Oostendorp, Colin J. Ewen, Elizabeth Hume, and Keren Rice. Oxford: Blackwell Publishing.

Kariņš, A. Krišjānis. 1996. The prosodic structure of Latvian. Ph.D. dissertation, University of Pennsylvania. Kaye, Jonathan. 1990. 'Coda' licensing. Phonology 7(2): 301-330.

Kehrein, Wolfgang. 2016. There's no tone in Cologne: Against tone-segment interactions in Franconian. In Segmental structure and tone, eds. Wolfgang Kehrein, Björn Köhnlein, Paul Boersma, and Marc van Oostendorp. Berlin: Mouton.

Kehrein, Wolfgang, and Chris Golston. 2004. A prosodic theory of laryngeal contrasts. Phonology 21(3): 325-357. 
Kiparsky, Paul. 2016. Livonian stød. In Segmental structure and tone, eds. Wolfgang Kehrein, Björn Köhnlein, Paul Boersma, and Marc van Oostendorp. Berlin: Mouton.

Köhnlein, Björn. 2011. Rule reversal revisited: Synchrony and diachrony of tone and prosodic structure in the Franconian dialect of Arzbach. Ph.D. dissertation, Leiden University.

Köhnlein, Björn. 2013. Optimizing the relation between tone and prominence: Evidence from Franconian, Scandinavian, and Serbo-Croatian tone accent systems. Lingua 131: 1-28.

Köhnlein, Björn. 2016. Contrastive foot structure in Franconian tone-accent dialects. Phonology 31(1): 87-123.

Krämer, Martin. 2009. The phonology of Italian. Oxford: Oxford University Press.

Kristensen, Marius. 1924. Vejledning til brugen af Danias lydskrift: Udarbejdet for udvalg for folkemål. København: H. H. Thieles bogtrykkeri.

Kristján Árnason. 2011. The phonology of Icelandic and Faroese. Oxford: Oxford University Press.

Kristoffersen, Gjert. 1992. Cirkumflekstonelaget i norske dialekter, med særlig vekt på nordnorsk. Maal og Minne 1992(1): 37-61.

Kristoffersen, Gjert. 2000. The phonology of Norwegian. Oxford: Oxford University Press.

Kristoffersen, Gjert. 2011a. Cirkumflekstonelaget i Oppdal. Norsk lingvistisk tidsskrift 29(2): 221-262.

Kristoffersen, Gjert. 2011b. Quantity in Old Norse and modern peninsular North Germanic. The Journal of Comparative Germanic Linguistics 14: 47-80.

Kusmenko, Jurij. 2008. Der samische Einfluss auf die skandinavischen Sprachen: Ein Beitrag zur skandinavischen Sprachgeschichte (Berliner Beiträge zur Skandinavistik 10). Berlin: Nordeuropa-Institut der Humboldt-Universität zu Berlin.

Ladd, D. Robert. 2004. Alignment allophony and European 'pitch accent' systems. Presentation at the 4th Conference on Tone and Intonation in Europe, Santorini.

Ladd, D. Robert. 2005. Alignement phonétique des contours intonatifs: allophonie et représentation lexicale. Presentation at the Seventh Annual Meeting of the Réseau Français de Phonologie, Aix-en-Provence.

Ladd, D.Robert. 2014. Simultaneous structure in phonology. Oxford: Oxford University Press.

Ladefoged, Peter. 2003. Commentary: Some thoughts on syllables—an old-fashioned interlude. In Papers in laboratory phonology, VI, eds. John Local, Richard Ogden, and Rosalind A. M. Temple, 269-276. Cambridge: Cambridge University Press.

Lahiri, Aditi, Allison Wetterlin, and Elisabet Jönsson-Steiner. 2005a. Lexical specification of tone in North Germanic. Nordic Journal of Linguistics 28(1): 61-96.

Lahiri, Aditi, Allison Wetterlin, and Elisabet Jönsson-Steiner. 2005b. Sounds definite-ly clitic: Evidence from Scandinavian tone. Lingue e linguaggio 2/2005: 243-262.

Larsen, Jørgen. 1976. Det sjællandske »tostavelsesord«. In Studier i dansk dialektologi og sproghistorie tilegnede Poul Andersen, eds. Kristian Hald, Christian Lisse, and John Kousgård Sørensen, 193-206. København: Akademisk forlag.

Liberman, Anatoly. 1975. Scandinavian circumflexes. Norsk tidsskrift for sprogvidenskap 29: 169-197.

Lodge, Ken. 1993. Underspecification, polysystemicity, and nonsegmental representations in phonology: An analysis of Malay. Linguistics 31(3): 475-520.

Lodge, Ken. 2007. Timing, segmental status and aspiration in Icelandic. Transactions of the Philological Society 105(1): 66-104.

Lorentz, Ove. 2008. Tonelagsbasis i norsk. Maal og Minne 2008(1): 50-68.

Martínez-Paricio, Violeta. 2013. An exploration of minimal and maximal feet. Ph.D. dissertation, University of Troms $\emptyset$.

McCarthy, John J. 2005. The length of stem-final vowels in Colloquial Arabic. In Perspectives on Arabic linguistics XVII-XVIII, eds. Mohammad T. Alhawary and Elabbas Benmamoun, 1-26. Amsterdam: John Benjamins.

Morén, Bruce. 2001. Distinctiveness, coercion, and sonority: A unified theory of weight. London, New York: Routledge.

Morén, Bruce. 2003. Danish stфd and Eastern Norwegian pitch accent: The myth of lexical tones. Presentation at the 13th Manchester Phonology Meeting.

Morén-Duolljá, Bruce. 2013. The prosody of Swedish underived nouns: No lexical tones required. Nordlyd 40(1): X years of CASTL phonology and L years of Curtness, eds. Sylvia Blaho, Martin Krämer, and Bruce Morén-Duolljá.

Odden, David. 2010. Features impinging on tone. In Tones and features: Phonetic and phonological perspectives, eds. John A. Goldsmith, Elizabeth Hume, and W. Leo Wetzels (Studies in Generative Grammar 107), 81-107. Berlin: De Gruyter. 
Page, Richard B. 1997. On the origin of preaspiration in Scandinavian. American Journal of Germanic Linguistics \& Literatures 9(2): 167-190.

Pearce, Mary D. 2013. The interaction of tone with voicing and foot structure: Evidence from Kera phonetics and phonology. Stanford, CA: CSLI Publications.

Pedersen, Anders. 1912. Dansk og urnordisk akcentuering. Arkiv för nordiskfilologi 28: 1-53.

Pétur Helgason. 2002. Preaspiration in the Nordic languages. Ph.D. dissertation, Stockholm University.

Piggott, Glyne. 1991. Apocope and the licensing of empty-headed syllables. The Linguistic Review 8(2-4): 287-318.

Prince, Alan S. 1980. A metrical theory for Estonian quantity. Linguistic Inquiry 11(3): 511-562.

Prince, Alan S. and Paul Smolensky. 1993. Optimality Theory: Constraint Interaction in Generative Grammar. Tech. rep. Rutgers University Center for Cognitive Science \& University of Colorado, Boulder.

Riad, Tomas. 2000a. Stöten som aldrig blev av: Generaliserad accent 2 i Östra Mälardalen. Folkmålsstudier 39: 319-344.

Riad, Tomas. 2000b. The origin of Danish stød. In Analogy, leveling, markedness, ed. Aditi Lahiri, 261-300. Berlin, New York: Mouton de Gruyter.

Riad, Tomas. 2009. Eskilstuna as the tonal key to Danish. In Proceedings FONETIK 2009, eds. Peter Branderud and Hartmut Traunmüller, 12-17. Stockholm: Department of Linguistics, Stockholm University.

Riad, Tomas. 2014. The phonology of Swedish. Oxford: Oxford University Press.

Rice, Curt. 1992. Binarity and ternarity in metrical systems: parametric extensions. Ph.D. dissertation, University of Texas, Austin.

Ringen, Catherine. 1999. Aspiration, preaspiration, deaspiration, sonorant devoicing and spirantization in Icelandic. Nordic Journal of Linguistics 22(2): 137-156.

Ringgaard, Kristen. 1960a. The apocope of disyllables. Phonetica 10(3-4): 222-230.

Ringgaard, Kristen. 1960b. Vestjysk st $\phi$ d. Aarhus: Universitetsforlaget.

Selkirk, Elisabeth O. 1980. The role of prosodic categories in English word stress. Linguistic Inquiry 11(3): 563-605.

Smith, Norval. 1999. A preliminary account of some aspects of Leurbost Gaelic syllable structure. In The syllable: Views and facts, eds. Harry van der Hulst and Nancy Ritter (Studies in Generative Grammar 45), 577-630. Berlin: Mouton de Gruyter.

Šurkalović, Dragana. 2013. Modularity, phase-phase faithfulness and prosodification of function words in English. Nordlyd 40(1): X years of CASTL phonology and L years of Curtness, eds. Sylvia Blaho, Martin Krämer, and Bruce Morén-Duolljá, 301-322.

Thorsen, Nina. 1982. Selected problems in the tonal manifestation of words containing assimilated or elided schwa. In Annual Report of the Institute of Phonetics, University of Copenhagen 16: 37-100.

van Oostendorp, Marc. 2016. Tone, final devoicing and assimilation in Moresnet. In Segmental structure and tone, eds. Wolfgang Kehrein, Björn Köhnlein, Paul Boersma, and Marc van Oostendorp. Berlin: Mouton.

Vaux, Bert. 2003. Syllabification in Armenian, Universal Grammar and the lexicon. Linguistic Inquiry 34(1): 91-125.

Vaux, Bert and Andrew Wolfe. 2009. The appendix. In Contemporary views on architecture and representations in phonology, eds. Eric Raimy and Charles Cairns (Current Studies in Linguistics 48), 101-144. Cambridge, MA: MIT Press.

Wetterlin, Allison. 2010. Tonal accents in Norwegian: Phonology, morphology and lexical specification (Linguistische Arbeiten 535). Berlin: De Gruyter.

Yip, Moira. 2002. Tone. Cambridge: Cambridge University Press.

Zec, Draga. 1988. Sonority constraints on prosodic structure. Ph.D. dissertation, Stanford University. 